\section{CITAÇÃo}

Mateus, A. (2020)

Recursos naturais de lítio,

Rev. Ciência Elem., V8(03):034.

doi.org/10.24927/rce2020.034

\section{EDITOR}

José Ferreira Gomes,

Universidade do Porto

\section{RECEBIDO EM}

29 de janeiro de 2020

\section{ACEITE EM}

04 de fevereiro de 2020

\section{PUBLICADO EM}

30 de setembro de 2020

\section{COPYRIGHT}

(C) Casa das Ciências 2020.

Este artigo é de acesso livre, distribuído sob licença Creative

Commons com a designação CC-BY-NC-SA 4.0, que permite a utilização e a partilha para fins não comerciais, desde que citado o autor e a fonte original do artigo.

rce.casadasciencias.org

\title{
Recursos naturais de lítio
}

\author{
António Mateus \\ DG/ IDL/ Universidade de Lisboa
}

A necessidade de opções suficientes para armazenamento de energia advém da evolução recente do setor eletroprodutor e tendência veloz para a eletrificação do setor automóvel. A solução tecnológica que hoje se afirma como a mais vantajosa envolve baterias recarregáveis de iões de lítio (LIB) com diferentes configurações, acopláveis em sistemas estacionários de armazenamento de energia e veículos elétricos. Esta solução deverá

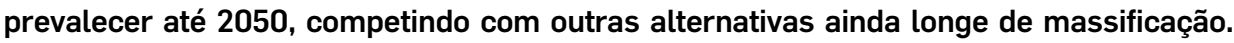
O fabrico em larga escala de LIB altera drasticamente o padrão de repartição do consumo de lítio nos mercados que abastecem diferentes setores industriais, exercendo forte pressão junto do limitado número de centros de mineração e transformação da matéria-prima natural no sentido de aumentarem rapidamente o seu ritmo de produção. Esta pressão tenderá a aumentar nos próximos anos a menos que, entretanto, seja possível incrementar de forma satisfatória as taxas de reciclagem das LIB e do lítio; atualmente, os valores das primeiras são insignificantes e menos de $1 \%$ do Li consumido é reciclado.

As reservas globais conhecidas totalizam $\approx 15 \mathrm{Mt}$ e estimativas conservadoras posicionam os recursos disponíveis em torno de $53 \mathrm{Mt}$, embora possam ascender a $62 \mathrm{Mt}$ se boa parte dos recursos inferidos for confirmada. Mantendo-se as taxas de esgotamento anual dos recursos remanescentes registadas nos últimos 5 anos, os picos de exploração serão atingidos a breve trecho, comprometendo muitas das linhas de desenvolvimento tecnológico imaginadas para o futuro, em particular as que se relacionam com a mobilidade eléctrica. Deste modo, a "corrida ao lítio" tem vindo a ganhar expressão crescente, sustentando investimentos significativos em prospecção e pesquisa mineral para melhor caracterizar os recursos existentes e aumentar as reservas globais. Esta é também a razão que explica o recrudescimento dos trabalhos de prospecção em Portugal, um dos grandes produtores de concentrados minerais litiníferos, ocupando desde há muitos anos a 6 ou $^{\text {a }}$ posição do ranking mundial com uma produção média anual de 15800 toneladas entre 1980 e 2016, mas cujo potencial se encontra por avaliar em detalhe.

Vivemos tempos de mudança acelerada que afectam de forma indelével as estruturas e inter-relações subjacentes aos modelos de desenvolvimento sócio-económico e respectivas interaçções com os Sistemas Naturais (vulgarmente denominadas "impactos ambientais"). As mudanças que temos vindo a experimentar, embora rápidas, consubstanciam um período de transição cuja amplitude e implicações são desconhecidas, não obstante as numerosas iniciativas orientadas para a Sustentabilidade, metas políticas a curto-médio prazo e antevi- 
sões diversas sobre o futuro da civilização Humana. As transições para economias de baixa intensidade carbónica inscrevem-se neste conjunto de iniciativas e os programas com elas relacionadas têm conferido relevância crescente às quotas de produção de electricidade usando sistemas tecnologicamente sustentáveis de energia (conhecidos como "energias renováveis"), assim como às medidas que visam a expansão consolidada da mobilidade eléctrica ${ }^{26,28,29,30,38,46}$. Estas duas linhas de acção, associadas a várias outras que resultam das macrotendências assinaladas em numerosos estudos sobre a (r)evolução tecnológica em curso, suscitam incertezas diversas sobre a disponibilidade futura de numerosas matérias-primas ${ }^{68,72,73}$. De entre os problemas identificados destacam-se os relacionados com: (i) acréscimos assinaláveis de pressão sobre a produção de matérias-primas, nomeadamente das que apresentam ainda baixas taxas de reciclagem ou cuja substituição não é possível e/ou economicamente viável; e (ii) possíveis roturas permanentes de abastecimento ou períodos intermitentes de escassez nos mercados de matérias-primas que possam lesar os planos de desenvolvimento gizados para o futuro. A título de exemplo, a insuficiência e/ou descontinuidade de abastecimento de Co, Li, Pt, alguns Elementos de Terras Raras, Ge, Ga, Ag e grafite natural, entre outros, poderá comprometer boa parte dos programas de neutralidade carbónica estabelecidos para muitos países, como Portugal. Por outras palavras e considerando os actuais níveis de desenvolvimento tecnológico, dificilmente será possível assegurar a produção massificada dos dispositivos de conversão e armazenamento de energia e dos motores elétricos previstos pelos referidos programas sem garantir acesso a quantidades elevadas daqueles "materiais funcionais", comercializadas a preços toleráveis.

Em 2016, cerca de 2/3 da nova capacidade instalada para geração de electricidade baseou-se em fontes renováveis de energia, principalmente eólica e solar, antecipando-se uma expansão global do débito associado a aerogeradores e centrais fotovoltaicas em torno de $759 \mathrm{GW}$ até $2022^{47,58}$. Este crescimento coloca importantes desafios ao armazenamento de energia e à gestão das redes de distribuição de electricidade, procurando o melhor balanço possível entre uma procura crescente e uma oferta cada vez mais suportada por fontes naturalmente intermitentes ${ }^{4}$. No setor automóvel, a produção e venda de veículos elétricos $(E V)$ [incluindo os alimentados a baterias (BEV), células de combustível (FCEV), híbridos (HEV) e híbridos Plug-in (PHEV)] crescem também de forma acentuada, prevendo-se incrementos entre 30 a $35 \%$ até 2040 no conjunto dos países onde hoje circulam mais de $2 / 3$ da totalidade dos carros de passageiros (i.e. países que integram a Organização para a Cooperação e Desenvolvimento Económico - OCDE - e a China). Aceitando estas previsões, teremos em circulação mais de 100 milhões de EV a partir de 2030 e uma produção anual estabilizada de 50 milhões EV a partir de $2050^{126,78 .}$

Atualmente, as baterias recarregáveis de iões de lítio (LIB) representam a solução tecnológica mais favorável para sistemas estacionários de armazenamento de energia a curto-médio prazo e aplicações EV mercê da sua resposta rápida, baixas perdas em modo de espera e eficiência elevada dos ciclos de carga-descarga $97,112,113,108,67,138,124$. A estas utilizações em franca expansão acrescem as taxas de crescimento rápido associadas à produção e consumo de baterias de elevada eficiência acopladas a uma miríade de equipamentos electrónicos portáteis de uso cada vez mais comum ${ }^{136,1,67}$. Por estas razões, as LIB passaram a dominar o mercado mundial de baterias recarregáveis em menos de três décadas, atingindo nos últimos anos quotas próximas de $85 \%$. Gradualmente, a China tornou-se o maior produtor mundial de LIB, assegurando 63,7 GWh em 2016, i.e. mais de 
$50 \%$ do valor global gerado ${ }^{130}$. As LIB deverão perdurar como solução dominante até pelo menos 2050, eventualmente com configurações diferentes das que conhecemos hoje, pelo que urge desenvolver cadeias específicas de valor industrial orientadas para a produção e reciclagem destas baterias. Contudo, a diversidade da tecnologia LIB é muito lata, não sendo limitada apenas pelo design, mas também pela combinação variável de materiais que podem ser usados na sua manufactura ${ }^{98}$. Considerando as taxas de crescimento das aplicações LIB, impactos maiores em vários mercados de matérias-primas são esperados, de entre os quais se destacam os do lítio ${ }^{131}$.

Nos últimos anos, sucessivos estudos têm avaliado a disponibilidade futura de lítio ${ }^{32}$, $134,40,39,53,57,77,122$. Os resultados obtidos, embora divergindo no detalhe, configuram cenários tranquilizadores quanto à suficiência dos recursos naturais de lítio conhecidos para suprir a procura que se antecipa como certa para as próximas décadas. Alguns destes estudos admitem a possibilidade de haver estrangulamentos temporários de abastecimento da matéria-prima litinífera (e consequente subida de preços) devido a demoras com a operacionalidade de novos empreendimentos mineiros e/ou dificuldades tecnológicas para manter ritmos de produção compatíveis com as necessidades de mercado. Contrariedades económicas, sociais e ambientais podem também contribuir para descontinuidades transitórias de abastecimento, causando a suspensão de lavra em alguns depósitos e retardando o início de novas operações extractivas. A análise cuidada dos pontos de partida assumidos nestes estudos recomenda, contudo, alguma prudência pois: (i) as condicionantes impostas pela continuidade geológica dos recursos (regulando a sua dimensão e teor) nem sempre são consideradas; e (ii) os diversos factores que determinam a exequibilidade da exploração (convertendo recursos em reservas, a partir das quais o lítio poderá ser economicamente produzido) raramente são ponderados. Deste modo, não se afigura legítimo tomar como certo e seguro o abastecimento futuro de lítio, como veremos adiante, o mesmo acontecendo com qualquer outra matéria-prima mineral. Mais, a natureza específica das infraestruturas de exploração e transformação mineral impede, salvo raras excepções, a introdução de alterações bruscas de procedimentos. Por isso, o ritmo de adaptação da produção mineira é, em regra, inferior à cadência imposta pelo crescimento da procura, registando ainda enormes dificuldades em acomodar as oscilações de mercado que caracterizam os períodos de transição entre ciclos de crescimento económico e/ou de desenvolvimento tecnológico. A estas condicionantes acrescem as relacionadas com o lançamento de novos centros produtores. Trata-se de uma tarefa exigente e demorada, estando cada vez mais sujeita a forte escrutínio público e requerendo (i) cumprimento de normas ambientais exigentes, para além de (ii) continuidade de investimento e, por isso, relativa estabilidade de mercado em prazos suficientemente dilatados; o que, cada vez mais, é difícil de assegurar, aumentando severamente o risco associado ao empreendimento.

A análise presente procura rever alguns dos aspectos críticos relacionados com os recursos globais de lítio, motivada pela evolução recente das taxas de esgotamento dos recursos remanescentes conhecidos. Em alguns tópicos a abordagem é necessariamente simples, sendo mais as questões levantadas do que as respondidas. Tal deve-se sobretudo à escassez de dados públicos sobre produção e reservas e/ou à sua harmonização incipiente, nem sempre abrangendo séries temporais suficientemente robustas para o efeito e/ou nem sempre organizando a informação com base nos mesmos critérios e unidades. A produção global bruta de concentrados de lítio (em toneladas métricas) ao longo da série 
temporal 1925-2016 disponibilizada pelos Serviços Geológicos Norte-Americanos (USGS) no seu website constituiu-se como o ponto de partida usado nesta abordagem, complementada sempre que necessário com a informação referente ao período 1980-2016 consultada no website dos Serviços Geológicos Britânicos (BGS), bem como com outros dados/informações reportados em estudos diversos, a seu tempo citados. Estes elementos de natureza global permitem, por fim, contextualizar algumas das principais implicações que potencialmente decorrem da confirmação do aumento expectável de recursos e subsequente delimitação e exploração de reservas litiníferas em Portugal.

\section{Mercado do lítio}

Repartição dos consumos

A utilização de produtos litiníferos registou variações apreciáveis nos últimos tempos como resultado da evolução tecnológica e/ou da expansão das quotas de mercado associadas a algumas aplicações. Até finais da primeira década do século XXI, o mercado de produtos litiníferos baseava-se fundamentalmente na comercialização de concentrados minerais diversos (sobretudo silicatos de lítio extraídos de sistemas pegmatíticos e canalizados para as indústrias da cerâmica e vidro) e compostos químicos (principalmente carbonato, hidróxido ou cloreto de lítio) obtidos através da transformação industrial de alguns concentrados minerais ou via exploração de precipitados salinos a partir da bombagem e tratamento de salmouras naturais em salares ${ }^{22,53,39}$. Durante este período, o carbonato de lítio $\left(\mathrm{Li}_{2} \mathrm{CO}_{3}\right)$ foi o principal composto transacionado (FIGURA 1 ) e tal-qual consumido por vários setores industriais, o que inclusivamente justificava a utilização generalizada da unidade "equivalente carbonato de lítio" (LCE = lithium carbonate equivalent) no relato da produção e uso desta matéria-prima. Ao carbonato de lítio, seguiam-se os diversos concentrados minerais passíveis de utilização directa em pastas cerâmicas, assim como na produção de vidro e de cimento com requisitos específicos. 0 consumo de hidróxido de lítio $\left(\mathrm{LiOH} . \mathrm{H}_{2} \mathrm{O}\right)$ na indústria dos lubrificantes, tal como de compostos organo-litiníferos (de onde se destaca o butilítio $-\mathrm{C}_{4} \mathrm{HgLi}$ ) no setor dos polímeros e do lítio metálico no exigente domínio das soldaduras especiais com alumínio usadas em número crescente de aplicações, não era também despicienda. 0 aumento acentuado das necessidades de lítio requeridas pelo setor das baterias recarregáveis, particularmente sentido desde 2013, perturbou de forma assinalável o balanço de mercado ${ }^{79,99}$. Este era um ponto de viragem esperado desde 2010, considerando apenas a produção de baterias para diversos equipamentos electrónicos portáteis (e.g. computadores portáteis, tabs, telemóveis, etc.), mas cuja magnitude se acentuou manifestamente com o advento dos EV. Porém, a ( $r$ )evolução desencadeada pelo setor das baterias não ficou por aqui, pois os recentes desenvolvimentos tecnológicos associados às baterias recarregáveis acopladas em EV têm contribuído para a substituição gradual do $\mathrm{Li}_{2} \mathrm{CO}_{3}$ pelo $\mathrm{LiOH} . \mathrm{H}_{2} \mathrm{O}$ (FIGURA 1). Mantendo-se esta tendência de consumo, a procura de $\mathrm{LiOH} . \mathrm{H}_{2} \mathrm{O}$ superará a de $\mathrm{Li}_{2} \mathrm{CO}_{3}$ a partir de 2022, podendo atingir $\approx 50 \%$ da quota de mercado em 2025 . 


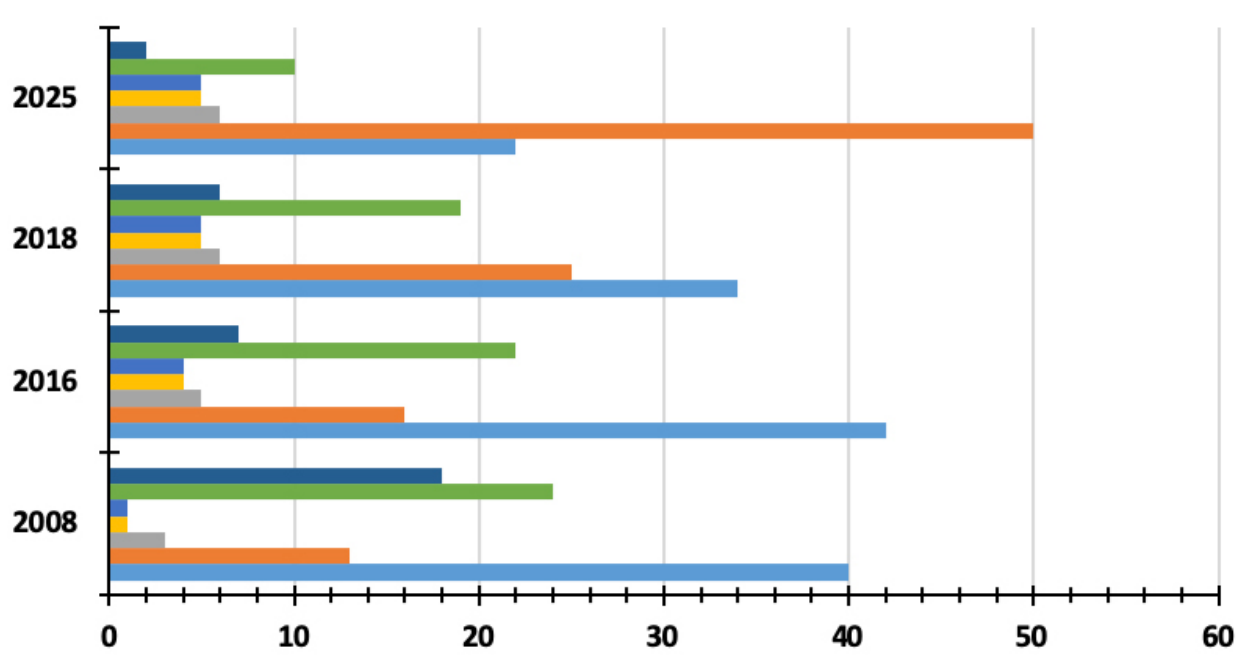

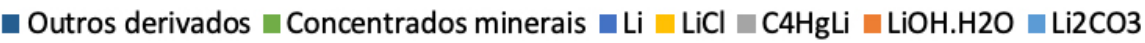

FIGURA 1. Repartição das quotas de consumo (\%) dos principais produtos de lítio com base na informação relatada em diversos documentos produzidos pela Roskill, seleccionando alguns anos de referência no período 2008 - 2018. Os valores percentuais para o ano de 2025 representam estimativas médias de várias projecções baseadas nas tendências de crescimento do mercado quanto a possíveis consumos dos referidos produtos litiníferos.

A escalada recente do setor das baterias é vertiginosa. Até 2017 registou taxas de crescimento variáveis entre 10 a $15 \%$ ao ano e o consumo de lítio associado ultrapassou pela primeira vez o valor canalizado para os setores da cerâmica e vidro (FIGURA 2). Desde essa altura, a quota de mercado do setor não tem parado de subir, esperando-se que em 2026 exceda 64\% do consumo global de lítio (mercado correspondente a 221 mil milhões de US\$ em 2024) ${ }^{123}$. Deste modo, em apenas 10 anos (2016 - 2026) a quantidade de produtos litiníferos absorvida pelos setores industriais como um todo poderá passar de 196 mil toneladas (kt) LCE para valores próximos de 1000 kt LCE (nas perspectivas mais expansionistas) o que, inevitavelmente, exigirá incrementos muito significativos da produção atual ${ }^{107,41,21,57,56}$.

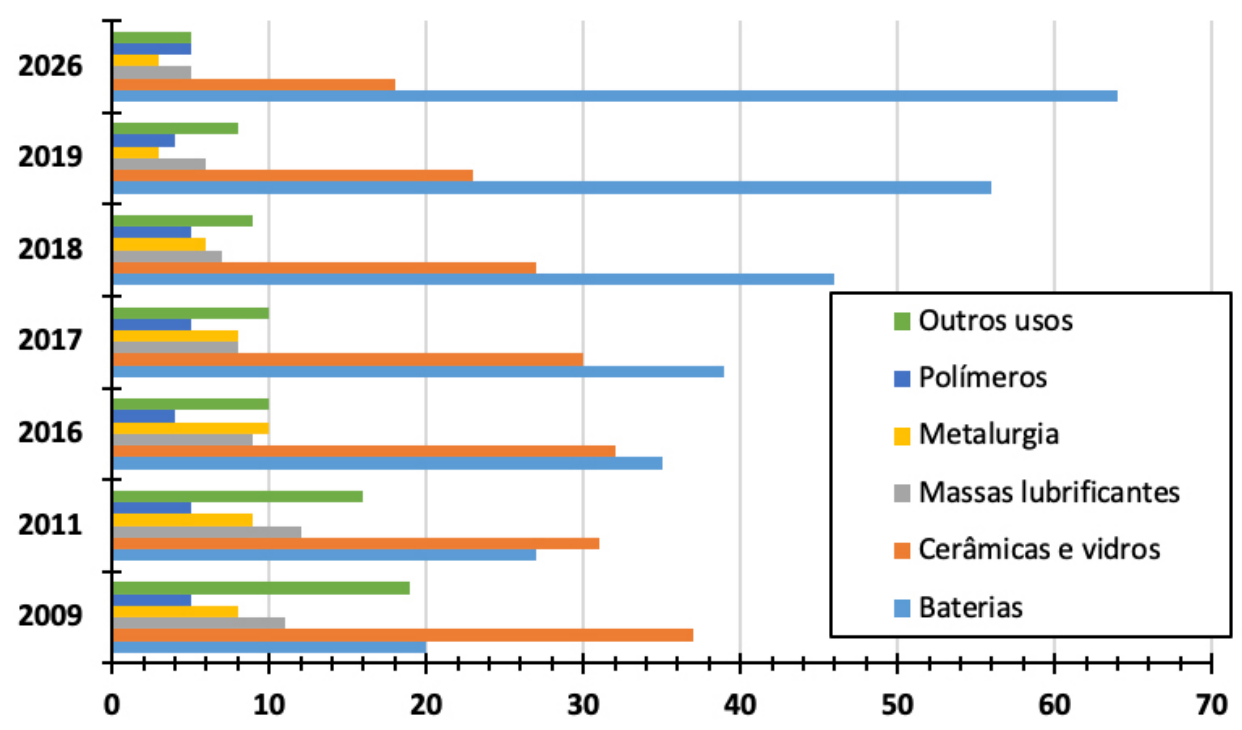

FIGURA 2. Repartição do consumo do lítio (\%) por vários setores industriais, recorrendo à informação disponibilizada pelo USGS para o período 2009 - 2018 e seleccionando alguns anos de referência (Jaskula, 2016, 2018, 2019). Os valores indicados para o ano de 2026 representam estimativas médias de várias projecções que tomam em consideração as tendências de mercado quanto à utilização massificada de LIB no setor automóvel. 


\section{Consumos futuros}

Cenários para 2050 quanto à demanda de metais para equipamentos electrónicos, tecnologias de geração e conversão de energia e EV ${ }^{18}$ indicam crescimentos de 10 a 20x para o caso específico do $\mathrm{Li}$ (e Co) em baterias recarregáveis (essencialmente dependente da massificação esperada para EV). Estes valores rectificam muitos dos resultados de estudos anteriores ${ }^{24,55,44,45,95,96,115}$, suscitando inquietações quanto à segurança de provimento futuro do mercado de lítio.

Nos últimos anos, a produção anual de lítio registou incrementos entre $\approx 8$ e $\approx 10 \%$ para acomodar necessidades relacionadas com o crescimento projectado de EV até 2030. Contudo, a manutenção das tendências referidas anteriormente irá exigir taxas anuais de aumento da produção entre $\approx 14 \%$ e $\approx 18 \%$ para precaver escassez de lítio no mercado a curto trecho ${ }^{40,5}$. Estes valores excedem consideravelmente a taxa anual compósita de 9,3\% prevista para o período 2018 - 2023 e dificilmente serão atingidos sem que novos centros de exploração e transformação mineral sejam criados; ou seja, abastecer o mercado global de lítio na próxima década representará um enorme desafio ${ }^{74,123,52,51}$. A pressão sobre a produção primária poderá ser atenuada se entretanto ocorrerem melhorias significativas nas tecnologias de baterias recarregáveis, reformulação e alargamento dos procedimentos de recolha e reciclagem das LIB e/ou desenvolvimento de alternativas viáveis em termos económicos para a sua substituição nas aplicações de maior impacto (líquidos iónicos em nano flow-cell batteries?).

Estudos comparativos diversos revelam que as LIB apresentam os melhores índices de desempenho de entre as baterias recarregáveis conhecidas ${ }^{127,125,120,98}$. 0 seu factor competitivo é ainda favoravelmente reforçado quando se considera o peso médio da bateria aplicada nas múltiplas configurações potencialmente envolvidas em componentes da "mobilidade eléctrica", as quais requerem armazenamento de grandes quantidades de energia; por isso, no conjunto geral das tecnologias de baterias, as LIB acabam por oferecer mais vantagens que todas as restantes $(\mathrm{Pb}, \mathrm{Ni}-\mathrm{Cd} \text { ou Ni-MH; e.g. })^{116,120}$. Durante alguns anos, o preço das LIB representava uma desvantagem competitiva, mas os progressos ocorridos entre 2010 e 2018 permitiram reduzir aquele valor ao ritmo de $\approx 20 \%$ /ano, passando de 1160 para 176 US\$/kWh (valores médios anuais). A pesquisa prossegue no sentido de determinar qual a melhor configuração LIB, garantindo a máxima densidade de energia, maior estabilidade térmica e melhores características de carga ${ }^{93,37,59}$. Tal fixará a quantidade de lítio requerida por bateria (bem como de outros elementos, em função das especificidades técnicas, como sejam o $\mathrm{Co}, \mathrm{Mn}, \mathrm{Fe}, \mathrm{P}, \mathrm{Al}, \mathrm{Ti})$, parâmetro determinante para avaliar em que medida a disponibilidade de lítio no mercado (e sua produção futura) pode afectar a implementação dos programas de neutralidade carbónica sem comprometer outro tipo de aplicações e/ou desenvolvimentos tecnológicos $7,80,135,19,35$.

A produção e uso de LIB acarretam, inevitavelmente, custos ambientais directos e indirectos, nem sempre considerados nas estimativas suporte aos programas de neutralidade carbónica $^{115,6,108}$. Por exemplo: (i) a tecnologia requerida para $1 \mathrm{Wh}$ de capacidade de armazenamento de energia tem um custo associado de $323 \mathrm{Wh}$ e $110 \mathrm{~g} \mathrm{CO}_{2}$ eq. de emissões (Peters et al., 2017); (ii) as LIB aplicadas nos EV representam mais de 65\% dos impactos directos e mais de metade da "pegada material" total associada ao fabrico destes veículos que, de acordo com os padrões tecnológicos vigentes, se posiciona acima da estimada para os veículos convencionais ${ }^{90,91,89,92,54,114}$. Assim, a maximização do ciclo de vida e da eficiên- 
cia dos ciclos de carga-descarga das LIB devem constituir-se como linhas fundamentais dos avanços tecnológicos relacionados com a produção destas baterias recarregáveis, para além das preocupações com a sua densidade energética ${ }^{112,113,6}$.

A percepção de que é preciso fazer algo, tornando as LIB e os processos relacionados com a sua manufactura mais eco-eficientes, encontra respaldo em números trabalhos que nos últimos anos se têm dedicado à análise dinâmica de fluxos materiais e construção de cadeias de valor específicas para o setor das baterias recarregáveis ${ }^{23,8,87,88,121,43,131}$. Estas investigações têm ganho particular ímpeto na China, cujo mercado não estará saturado antes de 2025 e menos de $40 \%$ dos materiais constituintes das LIB em fim-de-vida podem ser reciclados com base nos mecanismos já existentes neste país ${ }^{117}$. Tal coloca pressão significativa na gestão de resíduos no presente e futuro.

0 armazenamento de materiais catódicos LIB resultantes do consumo chinês aumentou de $\approx 301 \mathrm{kt}$ para $\approx 366 \mathrm{kt}$ entre 2013 e 2016 . Considerando as taxas de consumo crescente de produtos integrando LIB e respectivo descarte, estima-se que até 2025 a acumulação daqueles materiais poderá atingir valores próximos de $390 \mathrm{kt}^{130,117}$, representando um recurso secundário muito significativo, não obstante ainda pouco explorado. Paralelamente, a reciclagem LIB tem vindo a ser investigada com maior intensidade, registando progressos interessantes e inovadores quanto à recuperação de vários metais (essencialmente por processos electroquímicos), mas ainda muito deficitários no que diz respeito ao lítio ${ }^{133,104,83,25,137,15,11,76}$. A este propósito importa não esquecer que todos estes processos consomem energia, água e vários outros compostos químicos, gerando também emissões líquidas e gasosas. Mais, há que garantir a viabilidade económica das cadeias de recolha selectiva e reprocessamento; e o balanço que hoje é possível fazer está muito longe de ser satisfatório. Vias complementares de desenvolvimento das cadeias de valor envolvendo LIB poderão também passar pela implementação de sistemas de permuta no setor automóvel que obviem tempos de espera durante a recarga, o que conduzirá à padronização dos modelos LIB de uso massificado, alteração das plataformas de acoplagem hoje usadas nos diferentes modelos EV $100 \%$ elétricos e profunda transformação das redes de distribuição de baterias e de apoio aos consumidores.

\section{Evolução dos preços}

A informação disponível sobre a evolução dos preços do lítio é escassa, por vezes inconsistente e nem sempre divulgada nas mesmas unidades. Registam-se ainda diferenças muito significativas dos preços quando se consideram produtos com diferentes graus de pureza e/ou mercados específicos em fases muito diferentes de evolução, por vezes averbando flutuações muito bruscas que acabam por não perdurar no tempo ${ }^{67}$. A volatilidade dos preços é bastante comum para as commodities minerais e, com demasiada frequência, reflectem somente estratégias lideradas por países ou grupos de empresas que visam o reforço da sua hegemonia no mercado internacional. Não obstante estas dificuldades, a evolução documentada entre 2005 e 2019 para os valores médios anuais com que o $\mathrm{Li}_{2} \mathrm{CO}_{3}$ e $\mathrm{LiOH} . \mathrm{H}_{2} \mathrm{O}$ foram comercializados (FIGURA 3) revela uma clara e sistemática valorização destes produtos que assim deverá continuar por mais alguns anos. Este registo é também elucidativo quanto à progressão diferenciada do valor associado ao hidróxido de lítio em comparação com o do carbonato de lítio, nomeadamente a partir de 2014. Em qualquer dos casos, porém, estes preços posicionam-se sempre muito acima dos que tipificam o valor 
comercial das matérias-primas minerais a partir das quais se produz o carbonato ou hidróxido de lítio. A título de exemplo, entre 2016 e 2019, a tonelada métrica de espodumena (um dos minerais de lítio economicamente exploráveis) foi comercializada a preços médios anuais que oscilaram entre US\$ 517 (em 2016) e US\$ 558 (em 2018), esperando-se para 2020 valores em torno de US\$550. Daqui se depreende também a enorme vantagem em subir na cadeia de valor dos produtos litiníferos por parte de quem assegura a produção das matérias-primas minerais.

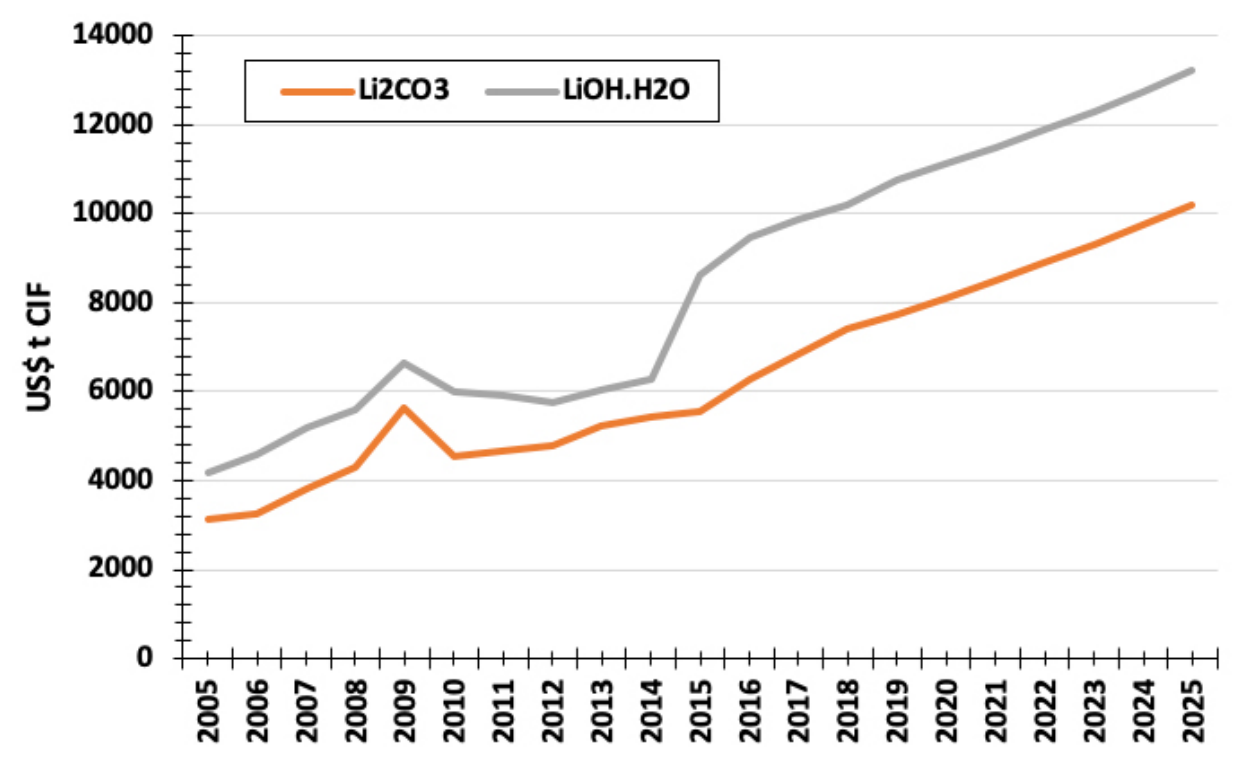

FIGURA 3. Evolução dos valores médios anuais de comercialização de Li2CO3 e LiOH.H2O com grau de pureza para o fabrico de LIB, entre 2005 e 2019 (US\$ por tonelada métrica CIF, i.e. contemplando o custo, seguro e frete). Os valores indicados para o período 2020-2025 correspondem a projecções que admitem a manutenção das taxas de crescimento médio registadas nos três últimos anos.

A tendência geral de subida de preços ditada por aumento (real e antecipado) da procura tem também permitido valorizar os projectos de prospecção e pesquisa de lítio em fase avançada de desenvolvimento. Esta evolução não é alheia à expectativa existente quanto à possibilidade dos "novos produtores" conseguirem prover $20-30 \%$ das necessidades de lítio projectadas para 2030, admitindo que a procura mantém a cadência crescente dos últimos cinco anos.

\section{Tipos de recursos e produção histórica}

A produção de lítio centra-se exclusivamente em duas tipologias de depósitos: (i) salmouras continentais associadas a salares; e (ii) pegmatitos. Como exemplos paradigmáticos do primeiro tipo figuram os vários conjuntos de salares que se distribuem na região de Atacama, suportando várias explorações no Chile e Argentina, bem como os salares que ocorrem na região de Qaidam (China), nomeadamente os lagos salgados de Zabuye de onde se recuperam quantidades elevadas de Li2CO3. O segundo tipo inclui os depósitos gigantes de Greenbushes (Austrália) e Manono-Kitolo (R.D. Congo), embora numerosos outros campos pegmatíticos de menor dimensão, com idade e distribuição geográfica diversa, pudessem ser referidos, incluindo os que ocorrem em território português. Para o conjunto das duas tipologias estimam-se reservas em torno de $14-15 \mathrm{Mt}$, ainda que 
nem todos os registos sigam códigos de relato comparáveis (e internacionalmente reconhecidos), podendo haver discrepâncias assinaláveis sobre os montantes tabelados em diferentes trabalhos ${ }^{134,39,129,24}$, assim como nas bases gerais disponibilizadas pelos Serviços Geológicos Norte-Americanos e Britânicos; sobre o total de recursos há maior convergência, como veremos na secção 3.1. Nas salmouras associadas a salares, os vários compostos de lítio (ver secção 3.2) correspondem a sais obtidos por evaporação de fluidos aquosos hipersalinos naturalmente acumulados ou artificialmente produzidos via injecção e subsequente captação de águas que durante o escoamento induzido interagem com um substrato salino. Nos campos pegmatíticos exploram-se diferentes fases minerais, destacando-se alguns silicatos (como a espodumena, petalite e lepidolite) e fosfatos (nomeadamente, mas não exclusivamente, a ambligonite), como será apresentado na secção 3.3 .

Aos recursos de salmouras associadas a salares e de pegmatitos acrescem os que, relacionados com outros sistemas naturais geradores de concentrações litiníferas interessantes, podem potencialmente vir a ser considerados no futuro em função do conhecimento geológico disponível, exequibilidade tecnológica e viabilidade económica da sua exploração e valorização. Neste conjunto potencial de recursos encontram-se algumas salmouras geotérmicas (e.g. Salton Sea, EUA) ${ }^{53}$, assim como salmouras dependentes de certos reservatórios de hidrocarbonetos ${ }^{36,53}$. São igualmente dignas de referência as acumulações de hectorite [esmectite de composição ideal $\mathrm{Na}_{0,3}(\mathrm{Mg}, \mathrm{Li})_{3} \mathrm{Si}_{4} \mathrm{O}_{1} \mathrm{O}(\mathrm{OH})_{2}$ ] geradas no decurso da alteração de rochas vulcânicas hospedeiras de sistemas geotérmicos de baixa temperatura em meio ácido e envolvendo fluidos hidrotermais alcalinos (e.g. King Valley, EUA) ${ }^{111}$, para além dos enriquecimentos em jadarite $\left[\mathrm{LiNaSiB}_{3} \mathrm{O}_{7}(\mathrm{OH})\right]$ resultantes da interacção prolongada de sedimentos clásticos com fluidos hidrotermais de relativa baixa temperatura quimicamente equilibrados com evaporitos (e.g. Jadar, Sérvia).

\section{Distribuição geográfica dos recursos}

De entre as várias recensões existentes sobre os recursos de lítio salienta-se a apresentada $^{39}$. De acordo com a compilação realizada por estes autores, os recursos de lítio associados a salmouras de tipo diverso perfaziam à data 26,9 milhões de toneladas (Mt), dos quais 25,4 Mt correspondiam a reservas (largamente em salares), enquanto os relacionados com concentrados silicatados ou fosfatados (sobretudo resultantes da exploração de pegmatitos) totalizavam 16,7 Mt, dos quais 11,7 Mt equivaliam a reservas. Neste estudo nada é dito sobre a natureza provada ou provável das reservas, mas é notório que os valores indicados para recursos não diferenciam de forma adequada os inferidos, indicados e medidos. Deste modo, os recursos globais apurados por 43,6 $\mathrm{Mt}^{39}$ - deverão ser entendidos como o valor máximo estimado à data da compilação que, não estando balizados por valores de concentração em lítio, só podem ser interpretados como recursos brutos; ou seja, a quantidade de lítio contida no recurso global rondará 2659,6 kt Li (= 43,6 Mt $\times 0,061)$, usando para efeitos de cálculo o factor de ponderação que considera a mistura de produtos obtidos em diferentes tipos de exploração (aferido com base na produção histórica). Esta compilação providencia uma informação adicional de especial relevância, à qual voltaremos na secção 5: de entre os grandes agrupamentos territoriais que formam a "geografia do lítio", a Europa figura como o único "importador líquido", contrastando com a auto-suficiência das regiões norte-americana, australiana e asiática; 
a esta informação acresce o comentário de que o essencial da produção europeia tem origem em Portugal.

A compilação apresentada ${ }^{129}$, embora menos exaustiva quanto às tipologias de recursos potenciais alternativos, toma em consideração critérios mais cuidados que a anterior, separando claramente as reservas dos recursos (indicados e medidos) para um total de 112 depósitos. As maiores discrepâncias referem-se a depósitos de salmouras associados a salares, o que se justifica face à dificuldade em estimar consistentemente as acumulações de sais e à inexistência de relatórios uniformizados por parte dos produtores. A compilação devida ${ }^{129}$, assim, mais realista, indicando como reservas de salmouras associadas a salares valores compreendidos entre 6,54 e 29,35 Mt; para esta tipologia de depósitos, os recursos estimados posicionam-se no intervalo 21,3-65,32 Mt. No que respeita às reservas associadas a pegmatitos, indicam montantes variáveis entre 5,57 e 8,17 $\mathrm{Mt}^{129}$, estimando como recursos quantidades distribuídas no intervalo 12,81 - 30,68 Mt. Obtêm-se assim para as reservas e recursos globais valores entre $\approx 13 \mathrm{e} \approx 37 \mathrm{Mt}$ e entre $\approx 34 \mathrm{e} \approx 96 \mathrm{Mt}$, respectivamente.

Qualquer entidade minimamente familiarizada com as incertezas intrinsecamente associadas às estimativas de reservas e recursos sabe que é sempre preciso alguma sensatez na interpretação destes números e que, atendendo aos diversos factores de natureza extrínseca (económicos, tecnológicos, fiscais, e outros), a "transformação" de recursos em reservas pode acontecer de intervalos de tempo muito variáveis ${ }^{17}$. Por isso, afigura-se imprudente tomar como certa a exploração da totalidade dos recursos conhecidos; do mesmo modo que não é aceitável tomar aqueles montantes como equivalentes ao total de lítio contido. Lamentavelmente, ambos os erros são cometidos com frequência, gerando leituras incautas da realidade que afectam sobremaneira a construção de cenários futuros sobre produção e riscos de abastecimento.

Em finais de 2014, as reservas globais conhecidas com elevado nível de segurança totalizavam $\approx 13 \mathrm{Mt}$ (em 2009, os Serviços Geológicos Norte-Americanos indicavam $11 \mathrm{Mt}$ como reserva base, i.e. a parte do recurso identificado que satisfaz o mínimo de critérios físicos e químicos específicos impostos por práticas de mineração e produção correntes). Nessa altura, 15,5 Mt representava uma referência razoável para as reservas/recursos globais passíveis de exploração a curto-médio prazo e o valor 30,5 Mt podia ser tomado como um tecto conservador para as reservas/recursos susceptíveis de suportar actividade mineira a um prazo mais dilatado. Nos últimos 5 anos, porém, o conhecimento disponível sobre recursos globais de lítio aumentou de forma evidente devido aos grandes investimentos realizados em actividades de prospecção e pesquisa mineral (FIGURA 4). 0 total de recursos hoje estimado ascende $a \approx 62 \mathrm{Mt}$, mas as reservas pouco subiram em termos comparativos, oscilando entre 14 e 16 Mt. Esta discrepância documenta de forma clara e simples o que temos vindo a reiterar sobre o cuidado que deverá existir quanto à disponibilidade futura de lítio nos mercados. Com grande probabilidade, uma fracção dos recursos delimitados nos últimos 5 anos reunirá condições para ser explorada, mas a construção das infraestruturas necessárias à extracção e transformação dessa matéria-prima mineral exigirá investimento significativo e tempo, retardando assim o abastecimento dos produtos litiníferos. Não são públicos os dados que precisam qual fracção destes recursos suportará novos centros mineiros, mas mesmo admitindo que a primeira é considerável, será muito difícil garantir plena operacionalidade de boa parte dos últimos na primeira 
metade da década que agora se inicia. Deste modo, o intervalo conservador entre $15 \mathrm{Mt}$ (reservas) e $53 \mathrm{Mt}$ (recursos) será usado nas modelações de produção futura apresentadas na secção 4. As limitações de produção que decorrem destas projecções para o futuro não devem ser tomadas como visões alarmistas ou pessimistas, mas sim como sinais de alerta que sustentam a necessidade de preparar em devido tempo e de forma consolidada as condições que permitam planificar e executar as actividades de prospecção e pesquisa mineral, assim como os estudos de viabilidade económica e de impacte ambiental requeridos pela abertura de novos centros produtores.

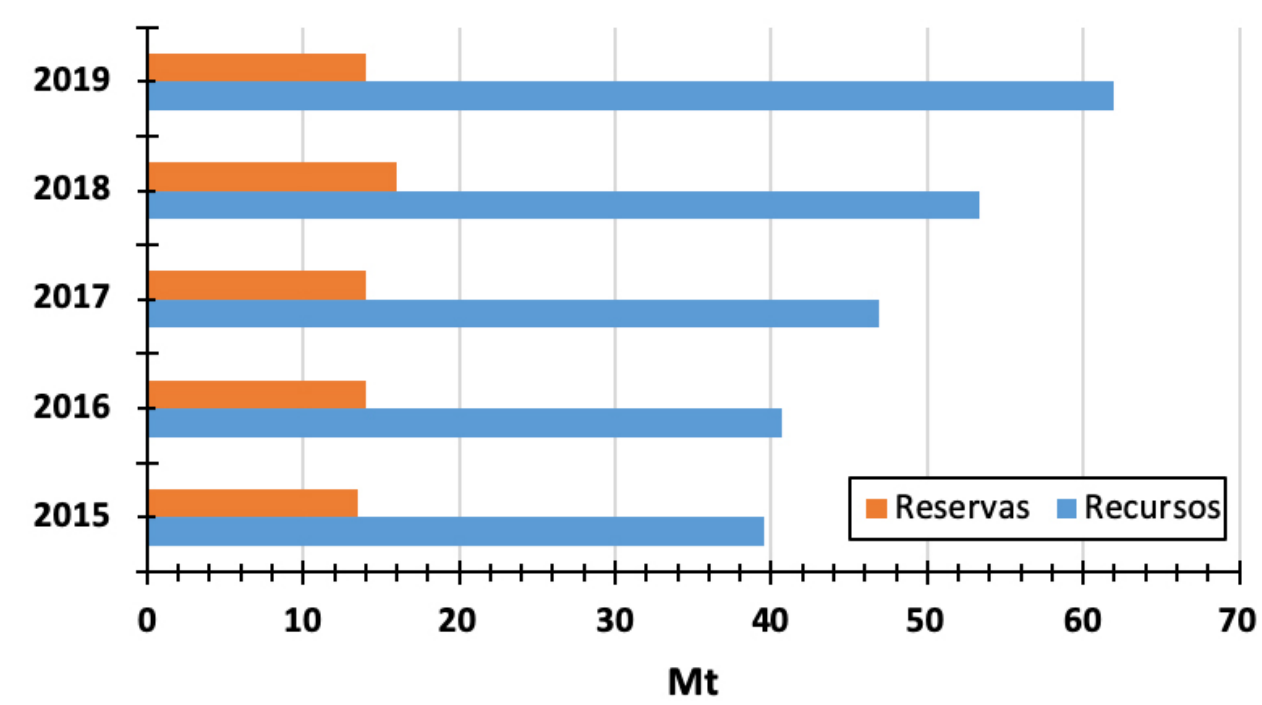

FIGURA 4. Recursos e reservas globais de lítio no período 2015 - 2019 (Jaskula, 2016, 2018, 2019).

Como nota adicional sublinhe-se: (i) que $3 / 4$ das reservas/recursos remanescentes recuperáveis a curto-médio prazo se confinam a pouco mais de 10 grandes depósitos; (ii) $91 \%$ das reservas globais conhecidas com elevado nível de segurança (14 Mt) se localizam no Chile, Argentina e Austrália (FIGURA 5A); e (iii) que o Chile e a Austrália são responsáveis por mais de $70 \%$ da produção mundial de concentrados minerais de lítio, tendo assegurado 67 kt do total produzido em 2018 (84,7 kt; FIGURA 5B). Daqui se retira que a produção mundial de lítio está muito estribada em termos geográficos, dependendo ainda em demasia da cadência de exploração de um número circunscrito de depósitos, não obstante a ampla distribuição geográfica de muitos dos recursos conhecidos, nomeadamente no que diz respeito aos do tipo pegmatito. 

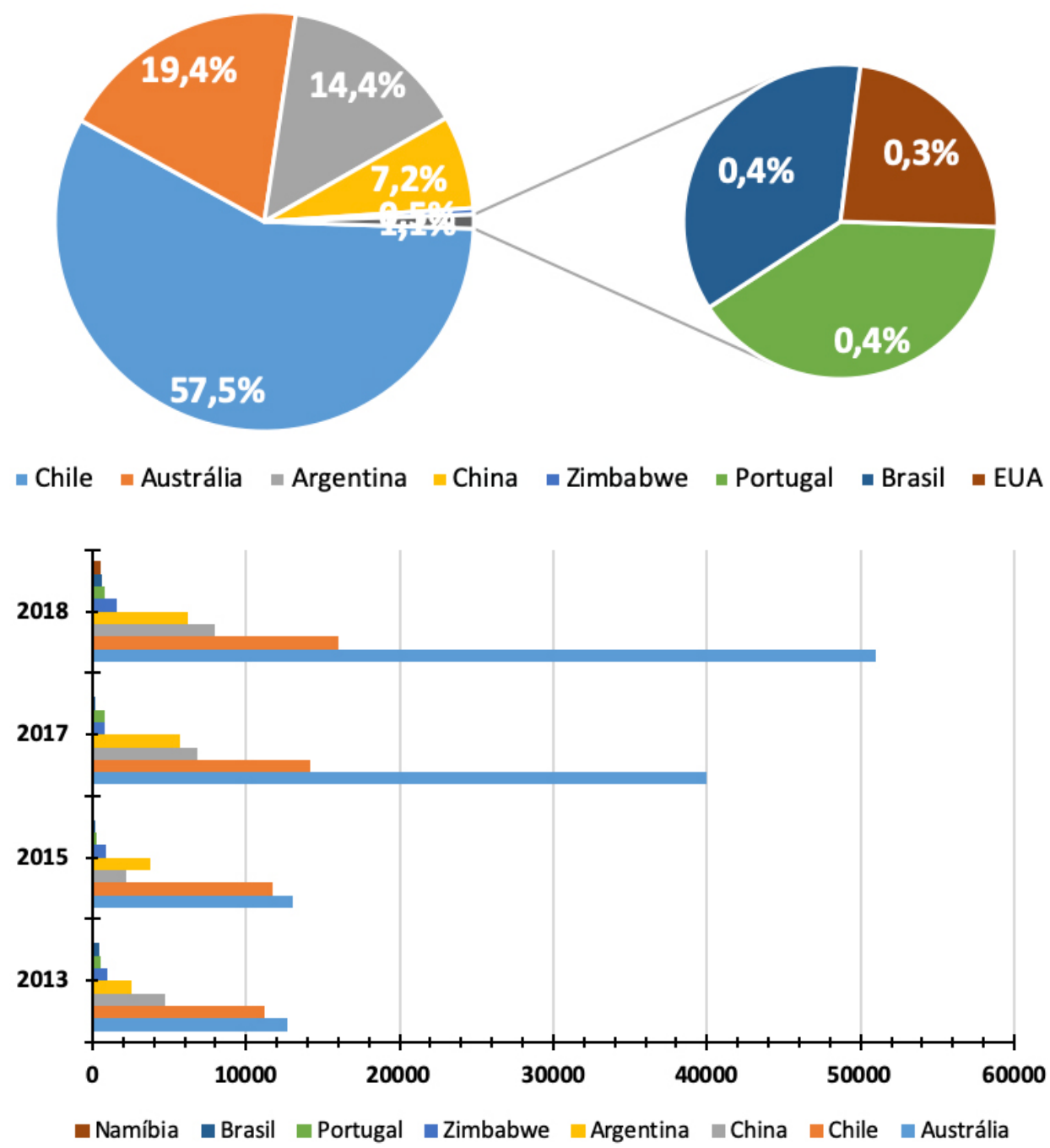

FIGURA 5. A) pie-chart. Distribuição geográfica das reservas de lítio em 2018 (valores consolidados). B) Repartição da produção mundial de lítio nos últimos anos (kt), documentando o aumento verdadeiramente explosivo da capacidade produtiva australiana nos últimos anos, tendo atingido 51 kt em 2018.

O crescimento gradual da produção australiana explica o facto dos concentrados minerais registarem nos últimos anos clara preponderância sobre os produtos obtidos via exploração de salares (FIGURA 6). Esta primazia, acontecendo pela primeira vez em 2004 e acentuando-se de forma evidente desde esse ano, não é alheia à subida dos preços do lítio (permitindo, suportar maiores custos de produção), nem à procura crescente deste elemento, nem tão pouco à introdução de aperfeiçoamentos tecnológicos capazes de garantir maior eficiência (e menor custo) dos processos de tratamento/ beneficiação dos concentrados de alguns silicatos. Deste modo, havendo dinâmica de mercado suficiente que permita explorar de forma rentável os sistemas pegmatíticos com custos de produção inferiores a $\$ U S \approx 6000 / t$ LCE será sempre possível garantir parte considerável das necessidades futuras com base na exploração deste tipo de depósitos. A este propósito note-se que os impactos ambientais associados a este tipo de extracção são, na maior parte dos casos, inferiores aos desencadeados pela exploração intensiva de salares, tipicamente formados sem sistemas naturais de maior vulnerabilidade. 


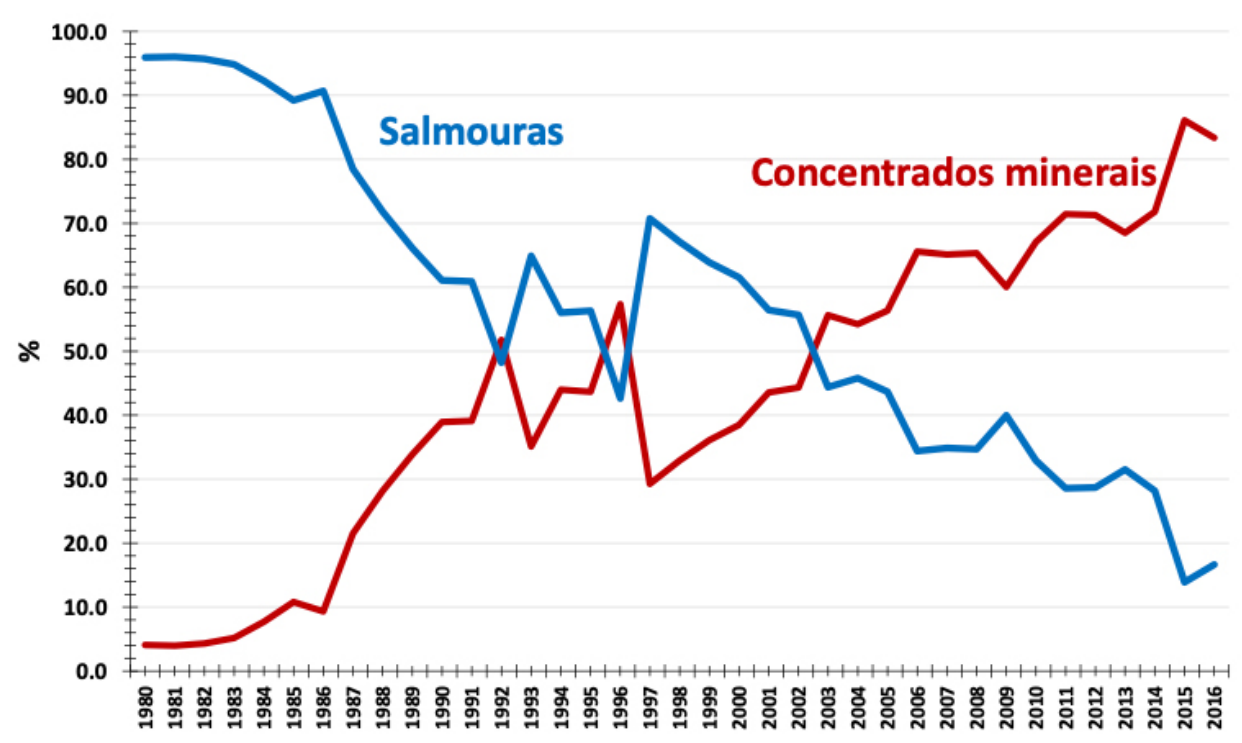

FIGURA 6. Evolução da produção mundial de lítio sob a forma de concentrados minerais explorados em sistemas pegmatíticos e em salmouras conforme dados disponibilizados pelo BGS.

\section{Depósitos e recursos do tipo salmoura continental}

Conforme referido anteriormente, os principais salares distribuem-se nas regiões de Atacama (Chile e Argentina) e de Qaidam (China). Na primeira região, destacam-se as explorações com maior longevidade no território chileno, muito embora seja especialmente evidente o enorme salto de produção argentina a partir de 1997 e, mais recentemente, a partir de 2014. $\mathrm{Na}$ segunda região, são particularmente importantes as explorações nos lagos salgados de Zabuye, as quais registaram quebra considerável a partir de 2014 não sendo ainda claro se esta diminuição foi, ou não, circunstancial. A FIGURA 7 ilustra a evolução da produção nestes países desde 1980 a 2016, e a TABELA 1 indica os valores de concentração típicos de alguns dos salares com maior significado económico; para informações complementares ${ }^{36,40,16,34}$.

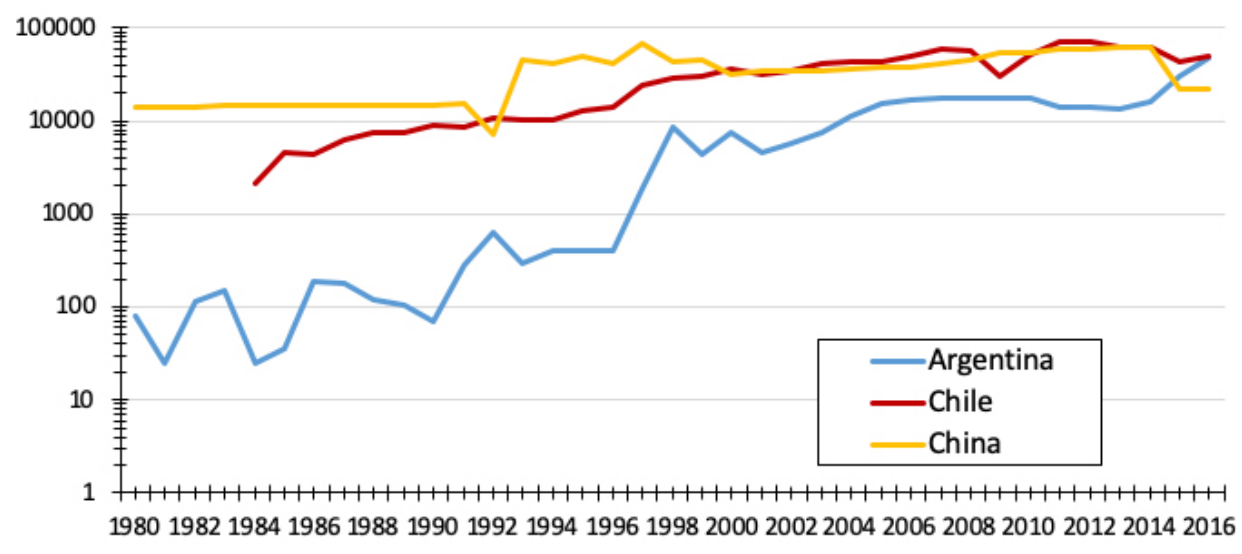

FIGURA 7. Evolução da produção de lítio em salares localizados na China, Chile e Argentina, conforme dados do BGS Valores de produção em toneladas ( $\mathrm{t}$ ). 
TABELA 1. Valores de concentração de Li e Cl em salares económicos (http://www.goldendragoncapital.com/lithium/)

\begin{tabular}{|c|c|c|c|c|c|c|}
\hline & $\begin{array}{c}\text { Clayton } \\
\text { Valley } \\
\text { (USA) }\end{array}$ & $\begin{array}{c}\text { Salar de } \\
\text { Atacama } \\
\text { (Chile) }\end{array}$ & $\begin{array}{c}\text { Salar de } \\
\text { Hombre } \\
\text { Muerto } \\
\text { (Argentina) }\end{array}$ & $\begin{array}{c}\text { Salar de } \\
\text { Rincon } \\
\text { (Argenti- } \\
\text { na) }\end{array}$ & $\begin{array}{c}\text { Zhabuye } \\
\text { (China) }\end{array}$ & $\begin{array}{c}\text { Qaidam } \\
\text { (China) }\end{array}$ \\
\hline $\mathrm{Li}$ (wt\%) & $0,02-0,04$ & $0,11-0,31$ & $0,05-0,06$ & 0,03 & $0,05-0,10$ & $0,01-0,03$ \\
\hline $\mathrm{Cl}$ (wt\%) & $10,10-11,70$ & $2,03-18,95$ & $15,80-16,80$ & 15,80 & $\begin{array}{c}12,16- \\
12,31\end{array}$ & $\begin{array}{c}9,20- \\
20,42\end{array}$ \\
\hline
\end{tabular}

Frequentemente, a literatura refere os salares de Uyuni (mormente os que se estendem para a Bolívia) como fonte potencial a ter em consideração no futuro, para a qual se estima um recurso total de 21,6 $\mathrm{Mt}$ ( $\approx 5,5 \mathrm{Mt}$ dos quais no salar Novo Mundo). Importa, contudo, ter em atenção os baixos conteúdos em lítio destes salares comparativamente com os valores que tipificam a maioria das explorações rentáveis na região andina (FIGURA 8), pelo que a sua viabilidade económica se afigura bastante fragilizada, mesmo em condições de mercado favoráveis.

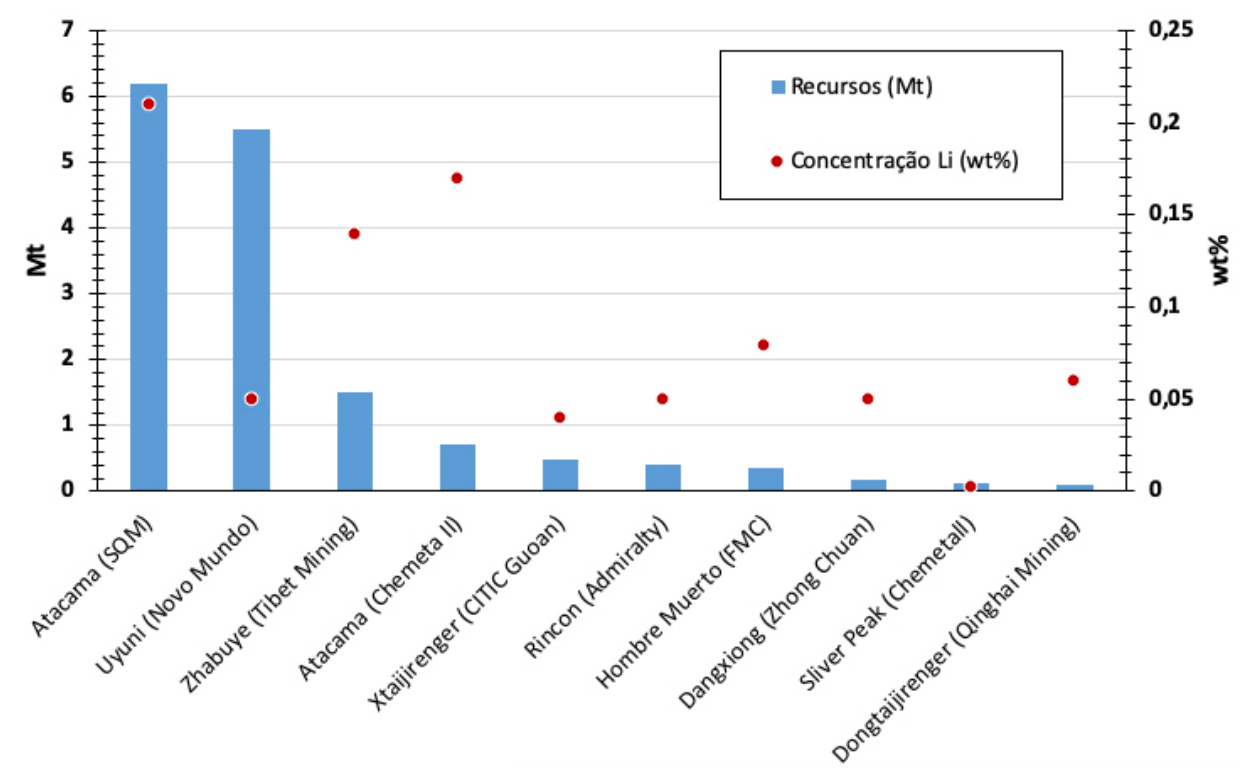

FIGURA 8. Recursos (barras, Mt) e teores médios de lítio (pontos, wt\%) para alguns dos principais salares concessionados a várias empresas, conforme dados divulgados em http://www.goldendragoncapital.com/lithium/.

Considerando a informação compilada nos trabalhos referidos na secção 3.1, facilmente se conclui que a dimensão média dos depósitos de salmoura se cifra em torno de 1,45 Mt Li. As características geológicas de alguns destes depósitos são compatíveis com capacidades de produção em larga-escala e longo período. Existem, contudo, vários aspectos que desaconselham fazer depender o abastecimento futuro de lítio da exploração intensiva destes sistemas geológicos de elevada vulnerabilidade, a saber: (i) distribuição geográfica limitada, em muitos casos confinada a territórios sujeitos a contextos geopolíticos instáveis; (ii) potencial para degradação rápida do recurso devido a diluição induzida pela injecção de água em salmouras não compartimentadas (o que acontece com enorme frequência); (iii) variações muito significativas de composição, que levantam numerosos pro- 
blemas quanto ao cálculo de reservas e à garantia de abastecimento de mercado; e (iv) impactos ambientais moderados a severos em muitas das unidades de produção. A propósito do terceiro item importa notar que as proporções de outros constituintes (nomeadamente, $\mathrm{K}, \mathrm{Mg}, \mathrm{Br}, \mathrm{B}$ ) condicionam bastante a eficiência de produção dos compostos de lítio, inibindo em particular a formação de $\mathrm{LiCl}$ ou conduzindo à retro-solubilidade do $\mathrm{Li}_{2} \mathrm{CO}_{3}$. Nestes sistemas, o lítio é, na verdade, um subproduto ou coproduto da exploração de uma larga variedade de sais com relativo baixo valor comercial e escoamento problemático, gerando, consequentemente, um volume exagerado de resíduos cujo acondicionamento/tratamento nem sempre é o mais adequado.

\section{Depósitos e recursos do tipo pegmatito}

Nos sistemas do tipo pegmatito são várias as fases minerais que incorporam ou podem incorporar lítio. Considerando a tecnologia disponível, apenas algumas destas fases minerais têm interesse económico, nomeadamente a espodumena, lepidolite, petalite, eucriptite e ambligonite; os seus conteúdos em lítio podem ser estimados em função da composição ideal (TABELA 2).

TABELA 2. Principais fases minerais litiníferas com interesse económico e respectivos conteúdos em lítio. As fases hectorite e jadarite, anteriormente mencionadas, são listadas para efeitos comparativos.

\begin{tabular}{|c|c|c|}
\hline & Composição ideal & Conteúdo Li (wt\%) \\
\hline Espodumena & $\mathrm{LiAlSi}_{2} \mathrm{O}$ & 3,7 \\
\hline Lepidolite & $\mathrm{K}_{2}(\mathrm{Li}, \mathrm{Al})_{5-6}\left(\mathrm{Si}_{6-7} \mathrm{Al}_{2-1}\right) \mathrm{O}_{2} \mathrm{O}(\mathrm{OH}, \mathrm{F})_{4}$ & $1,39-3,60$ \\
\hline Petalite & $\mathrm{LiAlSi}_{4} \mathrm{O}_{10}$ & $1,60-2,27$ \\
\hline Eucriptite & $\mathrm{LiAlSiO}_{4}$ & $2,10-5,53$ \\
\hline Ambligonite & $\mathrm{LiAl}\left(\mathrm{PO}_{4}\right)(\mathrm{F}, \mathrm{OH})$ & $3,40-4,70$ \\
\hline Hectorite & $\mathrm{Na}_{0,3}\left(\mathrm{Mg}, \mathrm{Li}_{3} \mathrm{Si}_{4} \mathrm{O}_{10}(\mathrm{OH})_{2}\right.$ & 0,54 \\
\hline Jadarite & $\mathrm{LiNaSiB}_{3} \mathrm{O}_{7}(\mathrm{OH})$ & 7,3 \\
\hline
\end{tabular}

Face aos dados compilados e divulgados pelos Serviços Geológicos Britânicos, a espodumena e lepidolite dominam largamente os concentrados minerais produzidos desde 1980 (FIGURA 9). Tal não é indiferente à hegemonia da Austrália (fundamentalmente assegurada via exploração de Greenbushes), assim como de outros contributos oriundos de extracções de menor dimensão em diferentes países, de entre os quais se destaca Zimbabwe, Portugal e Brasil (FIGURA 10). Note-se a este propósito que o ritmo da produção portuguesa tem condicionado em absoluto a evolução global da produção de lítio sob a forma de lepidolite; e tal deverá representar apenas uma pequena parte do que é possível explorar rentavelmente em Portugal, como veremos em secções posteriores. 


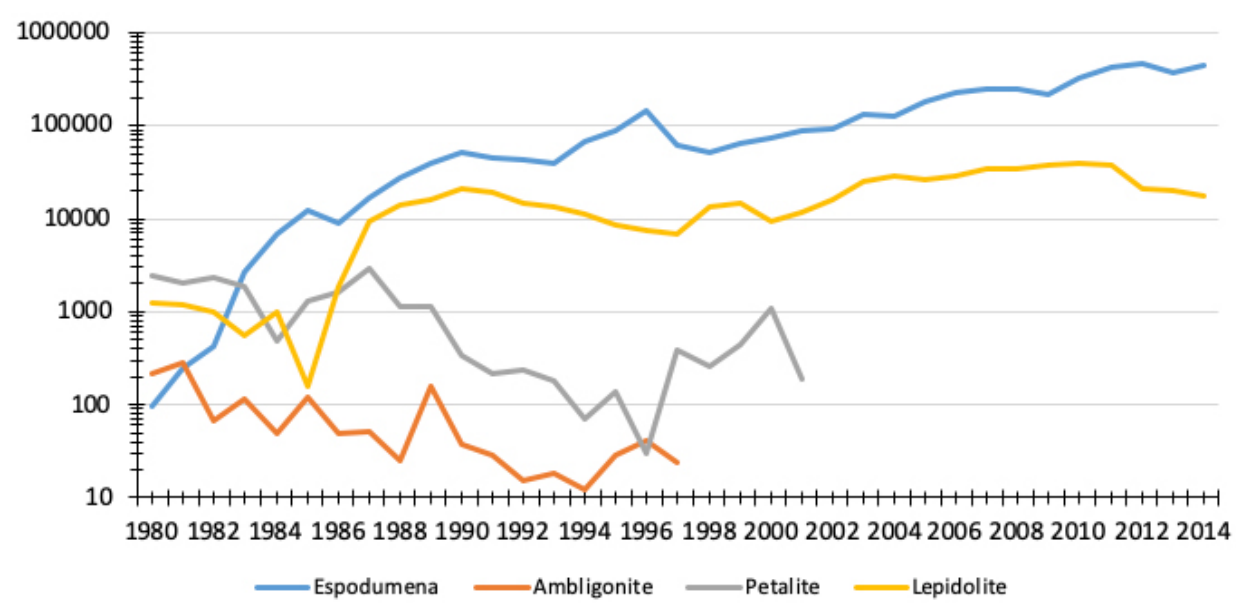

FIGURA 9. Evolução da produção mundial de concentrados minerais litiníferos em sistemas pegmatíticos, conforme dados do BGS. Valores de produção em toneladas ( $\mathrm{t})$.

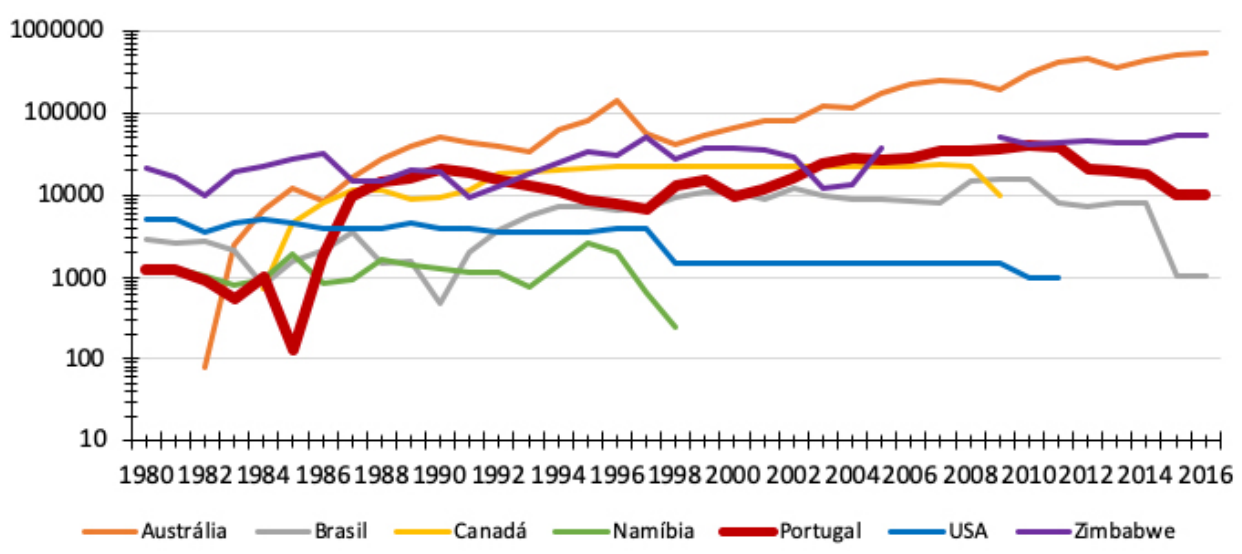

FIGURA 10. Evolução da produção de concentrados minerais litiníferos em sistemas pegmatíticos localizados em diferentes países, conforme dados do BGS. Valores de produção em toneladas (t).

Fazendo novamente uso das compilações apresentadas nos trabalhos referidos na secção 3.1, é possível concluir que a dimensão média dos depósitos do tipo pegmatítico se cifra em torno de $0,11 \mathrm{Mt} \mathrm{Li}$, sendo por isso bastante inferior à indicada para os de tipo salmoura. Daqui resultam, ainda em termos comparativos, menores capacidades para produção a larga-escala e longo período por depósito individual. Todavia, importa balançar estes aspectos menos vantajosos com três outros de importância capital, a saber: (i) a distribuição geográfica dos depósitos do tipo pegmatito é bem mais alargada e substantivamente menos vulnerável a instabilidades geopolíticas regionais; (ii) é possível conjugar explorações de diferentes dimensões e âmbitos, diversificando a produção e optimizando a lavra, assim como os procedimentos de tratamento e beneficiação, canalizando apenas os concentrados de maior teor para o fabrico de carbonato e/ou hidróxido de lítio; e (iii) há sempre a possibilidade de obter subprodutos variados com valor económico (e.g. estanho, tântalo, nióbio e berílio). São igualmente dignos de nota, a maior fiabilidade dos valores de produção e/ou de cálculo de reservas em sistemas pegmatíticos, bem como o menor impacto ambiental associado à sua exploração, permitindo harmonizar de forma célere e aceitável as perturbações causadas pela lavra mineira nos fluxos de massa naturalmente 
estabelecidos entre os reservatórios terrestres. Adicionalmente, a possibilidade de reduzir de forma muito significativa os resíduos de extracção deve também ser ponderada como vantagem acrescida; ou seja, caso o empreendimento seja devidamente estruturado nesse sentido, será possível escoar para diferentes setores de mercado a larga maioria dos produtos minerais gerados na exploração, facilitando assim a execução dos planos de recuperação/mitigação ambiental. Estas razões explicam, em boa parte, o aumento do investimento em prospecção de sistemas pegmatíticos em detrimento dos salares, mantendo ainda em suspenso muitos dos projectos mais promissores relacionados com outros tipos de salmoura e com as acumulações menos comuns de hectorite ou jadarite. 0 interesse crescente pelos sistemas pegmatíticos de idade Paleozóica em Portugal não é, por isso, ocasional, integrando-se nesta lógica de acção que tem por principais objectivos a identificação de novos depósitos e delimitação de novas províncias litiníferas para assim melhor responder às necessidades que se antecipam para o mercado mundial.

\section{Projecções futuras da produção}

0 registo histórico da produção constitui a base de qualquer exercício que procure projectar o futuro da actividade mineira tomando como referência o valor dos "recursos totais recuperáveis" ( $U R R=$ Ultimate Recoverable Resources). Conforme documentado na secção 3.1, o valor $15 \mathrm{Mt}$ afigura-se como bastante razoável para $U R R$ passível de exploração rentável a curto-médio prazo; de forma similar, $53 \mathrm{Mt}$ pode ser tomado como um tecto conservador de $U R R$ capaz de suportar actividade mineira a um prazo mais dilatado. A série temporal mais longa e harmonizada para a produção de lítio é apresentada pelos Serviços Geológicos Norte-Americanos, reportando valores brutos de produção desde 1925 a 2016, os quais podem ser, grosso modo, convertidos em produção líquida de lítio após multiplicação por 0,061.

Os valores de produção anual $q(t)$ ajustam-se bastante bem $\left(r^{2}=0,96\right)$ a uma curva polinomial de $5^{\mathrm{a}}$ ordem, transcrevendo vários ciclos de amplitude variável, o último dos quais mantendo taxas de crescimento altas e contínuas desde ca. 1993 (FIGURA 11). Como resultado, a produção acumulada $Q(t)$ ultrapassou $10 \mathrm{Mt}$ em 2013, aproximando-se rapidamente do valor $U R R$ limiar (15 Mt). Significa isto que o total dos recursos remanescentes $\left(R_{r}\right)$ classificados como reservas se afigura exíguo face às necessidades antecipadas como certas para o futuro próximo. 


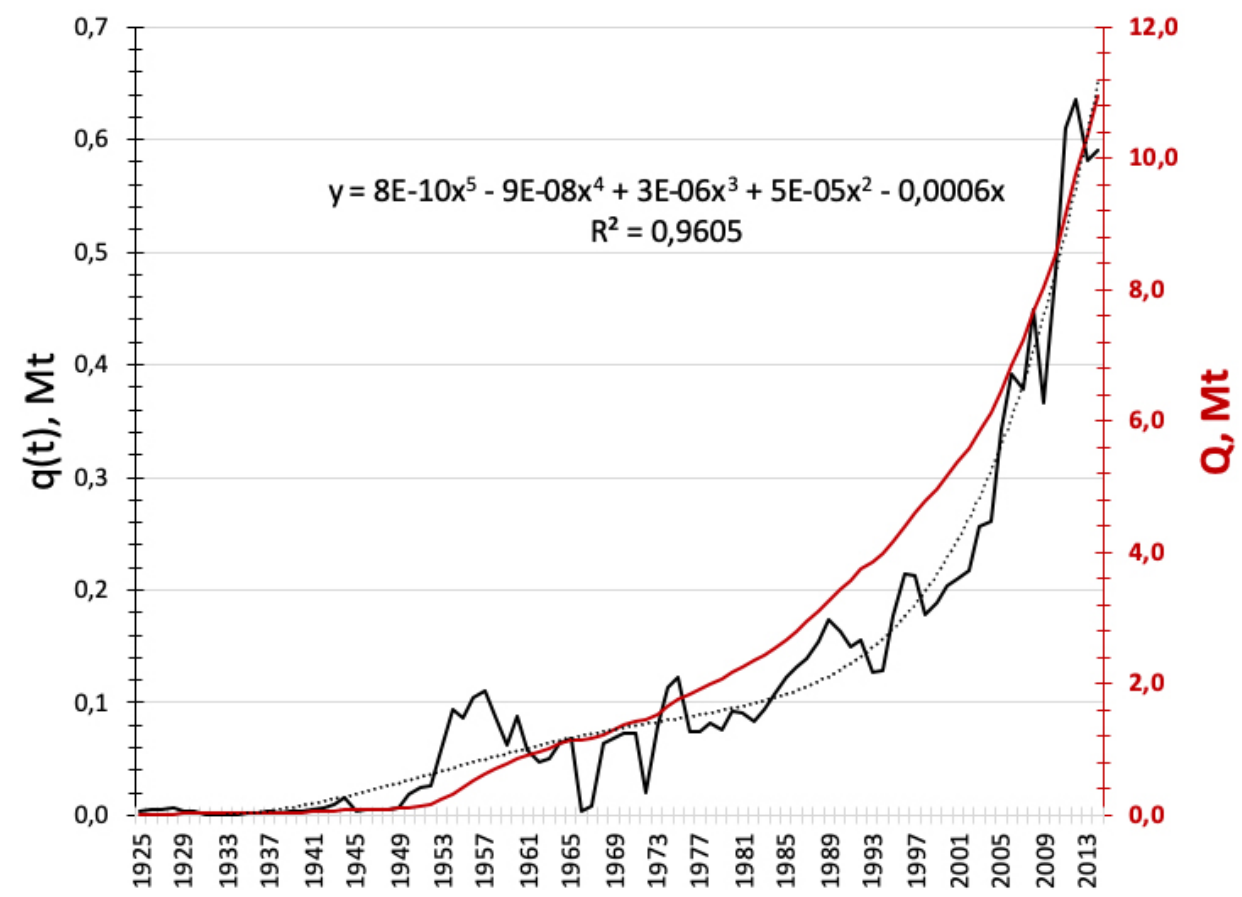

FIGURA 11. Registo da produção bruta histórica (anual e acumulada), conforme dados do USGS.

Daqui se infere que o aumento registado pela taxa de esgotamento destes recursos remanescentes nos últimos anos é preocupante, exigindo cuidados acrescidos com a sua gestão e a necessidade de lançar novas unidades de produção baseadas nos projectos mais promissores, cuja viabilidade económica e ambiental se encontra assegurada. Concretizando:

$$
R_{r}=R_{0}-Q(t)+\sum r^{\prime}
$$

onde $R_{r}$ representa o recurso remanescente no tempo $t ; R_{0}$ o recurso base estimado no tempo $t(=U R R) ; Q(t)$ produção cumulada nesse mesmo ano e $r^{\prime}$ o total apurado com as revisões dos recursos/reservas passíveis de exploração a curto prazo. Numa abordagem estática (pois não existem dados que permitam apreciar o problema de outra maneira), $r^{\prime} \approx 0$, resultando então:

$$
R_{r}=R_{0}-Q(t) \equiv R_{r}=U R R-Q(t) \equiv U R R=R_{r}+Q(t)
$$

Assim, a percentagem de $U R R$ anualmente extraído corresponde a uma taxa de esgotamento que se expressa na forma:

$$
d_{U R R, t}=\frac{q(t)}{Q(t)+R_{r}}=\frac{q(t)}{U R R_{t}}
$$

Este modo de apreciar o problema é, contudo, relativamente superficial, sendo bastante mais relevante saber a que taxa os recursos remanescentes estão sendo explorados (esgotados), a qual pode ser calculada com base em: 


$$
d_{R R R, t}=\frac{q(t)}{R_{r}}=\frac{q(t)}{U R R_{t}-Q(t)}
$$

Verifica-se, assim, que nos últimos anos as taxas de esgotamento anual de $U R R\left(d_{U R R, t}\right)$ se posicionaram no intervalo 1,5 a 2,5\% (FIGURA 12), algo que poderá não suscitar grande preocupação. Porém, a progressão obtida para $d_{R R R, t}$ é muito clara quanto aos efeitos decorrentes da produção realizada na última década (FIGURA 13) e, em especial, nos últimos 5 anos: usando o valor $U R R$ limiar de $15 \mathrm{Mt}$ (reservas consolidadas), as taxas de esgotamento anual das quantidades remanescentes têm vindo a crescer a um ritmo alarmante, ultrapassando muito recentemente a barreira (insustentável por muito tempo) dos $10 \%$. Claro que as perspectivas melhoram consideravelmente se o valor referência corresponder ao tecto conservador para o total dos recursos (53 Mt). Ainda assim, é legítimo perguntar qual o modelo matemático adequado à modelação da produção futura e subsequente análise quanto ao seu impacto potencial sobre os recursos conhecidos?

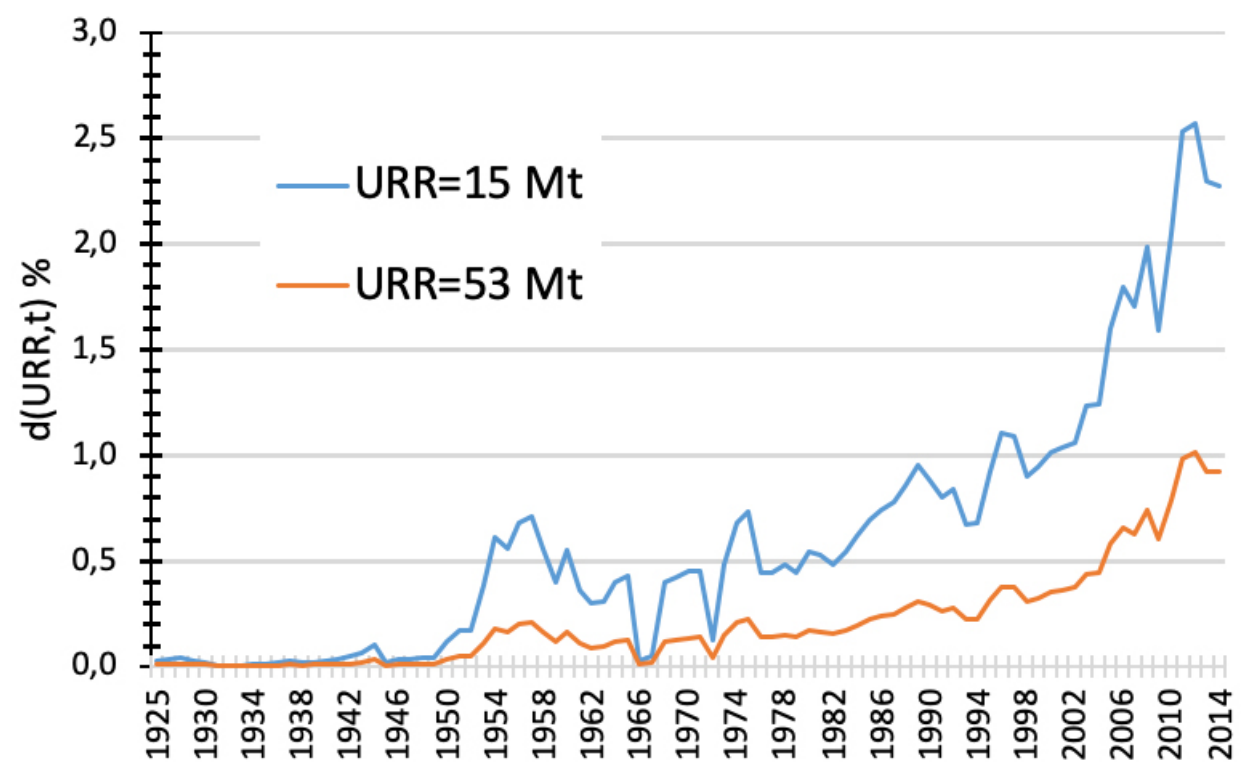

FIGURA 12. Evolução das taxas de esgotamento anual de URR, conforme dados do USGS. 


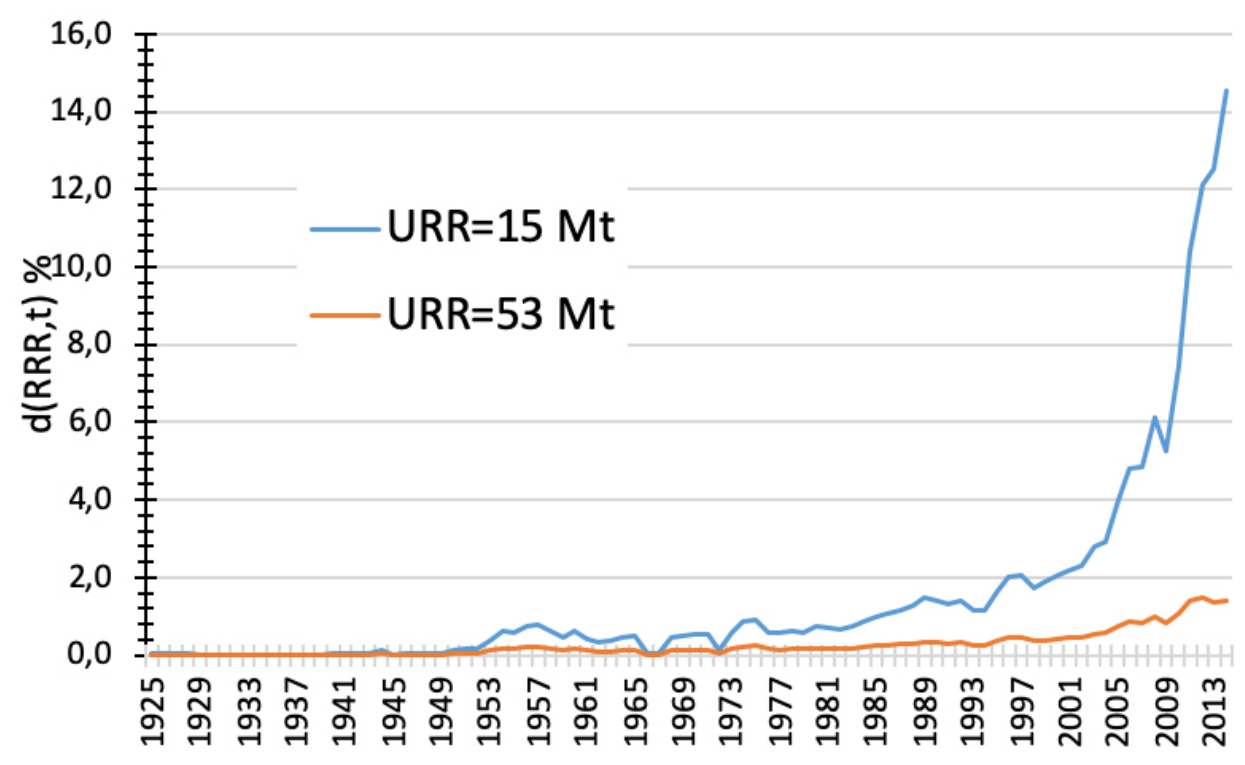

FIGURA 13. Evolução das taxas de esgotamento anual dos recursos remanescentes, conforme dados do USGS.

\section{Modelos}

Os modelos de usufruto de recursos finitos são basicamente descritos por duas funções distintas: (i) relações que expressam a evolução da produção anual em função do tempo, conduzindo a curvas em "forma de sino" simétricas ou assimétricas, variavelmente achatadas; e (ii) funções que traduzem a produção acumulada ao longo do tempo, limitadas por um valor URR. A equação genérica para as primeiras funções é conhecida como "modelo geral de Verhulst":

$$
q(t)=U R R(t) \times \frac{k}{n} \times \frac{\left(2^{n}-1\right) e^{(k(t-t m))}}{\left[1+\left(2^{n}-1\right) e^{(k(t-t m))}\right]^{\frac{n+1}{n}}}
$$

onde $k$ representa a taxa de crescimento de $q(t), n$ o "parâmetro de forma" e $t_{m}$ o ano em que se regista o pico de produção; quando $k=1, n=1$ e $t_{m}=50$ a distribuição de $q(t)$ é simétrica e reproduz a "curva de Hubbert"; mantendo $k=1$ e $t_{m}=50$, as curvas que materializam a evolução de $q(t)$ afastam-se da simetria e tornam-se menos ou mais agudas (transcrevendo lavras variavelmente distribuídas no tempo) consoante os valores de $n$ (FIGURA 14). 


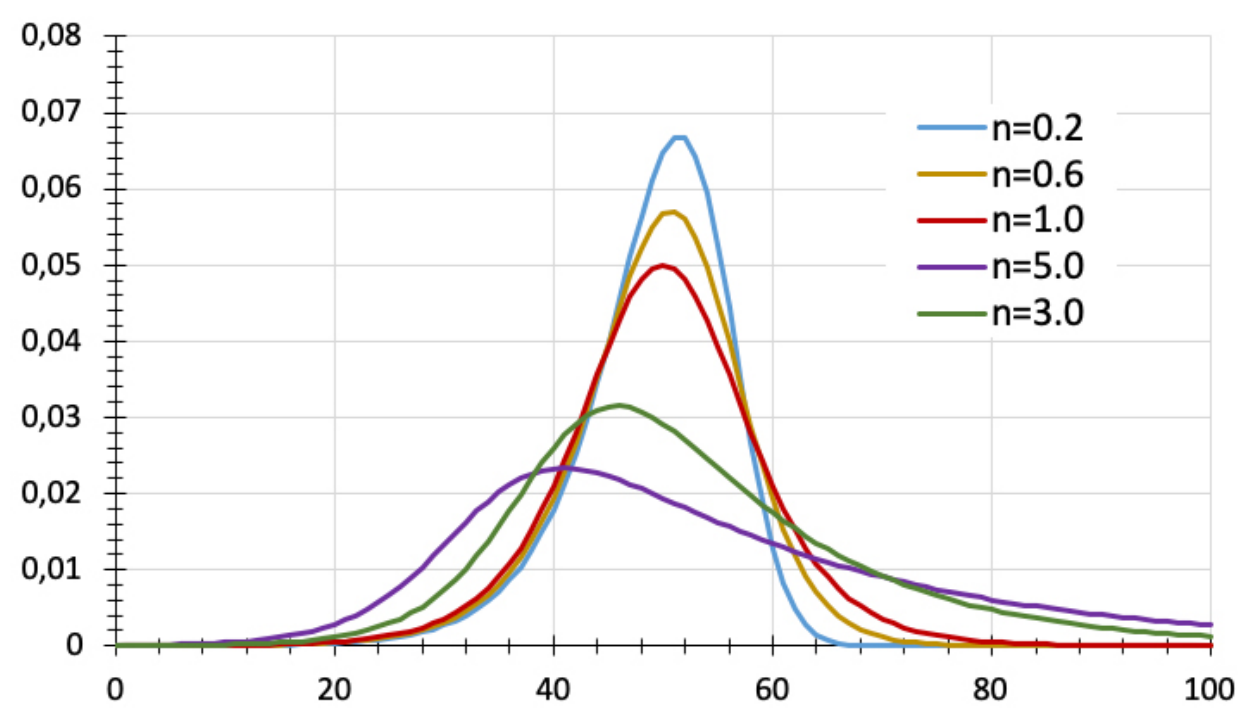

FIGURA 14. Curvas de produção anual ao longo de 100 anos simuladas com o modelo geral de Verhulst, considerando $U R R(t)$. Note-se a variação das características da curva em função dos valores tomados por $n$.

A equação geral que transcreve as segundas funções é conhecida como "modelo de Richards":

$$
Q(t)=U R R(t) \times\left[1+b \times e^{(-k(t-t m))}\right]^{-1 / b}
$$

onde, uma vez mais, $k$ representa a taxa de crescimento de $Q(t), b$ o "parâmetro de forma" e $t_{m}$ o ano em que se regista o pico de produção; quando $b=1, k=0,2$ e $t_{m}=50$ a distribuição de $Q(t)$ segue uma curva logística simétrica; quanto $b \rightarrow 0$, a equação reproduz o modelo de Gompertz (FIGURA 15).

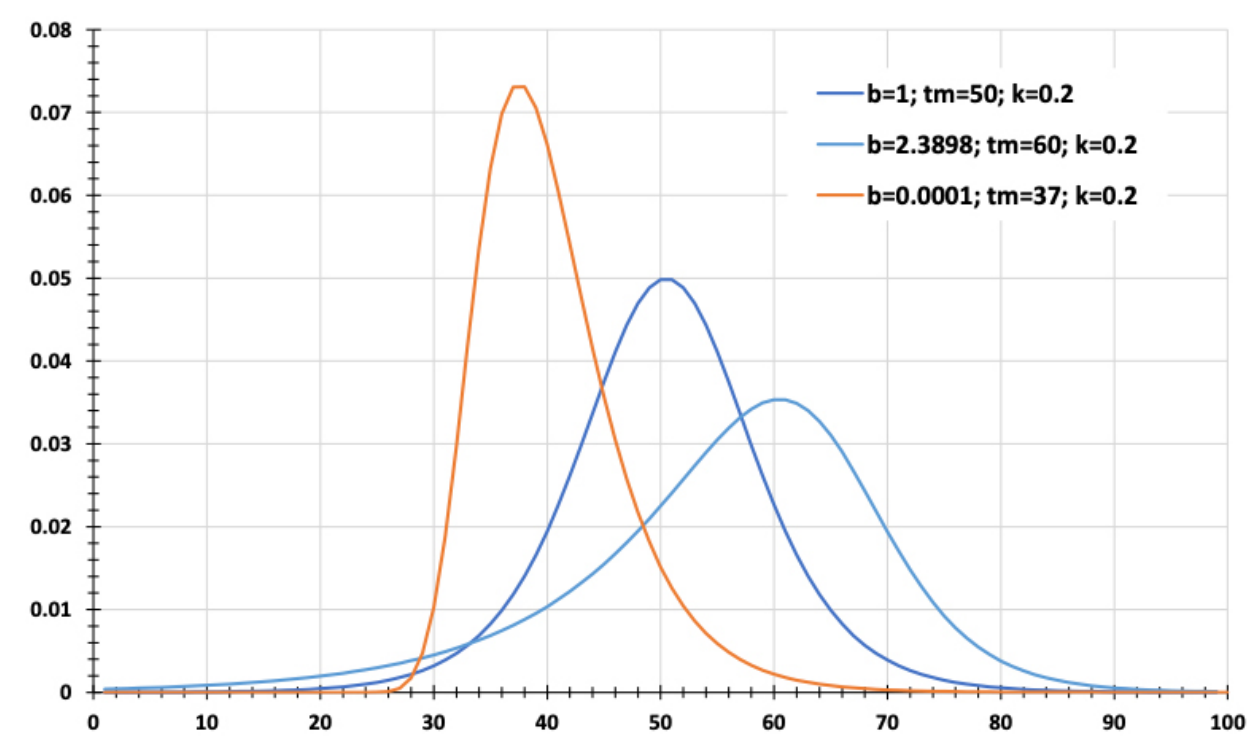



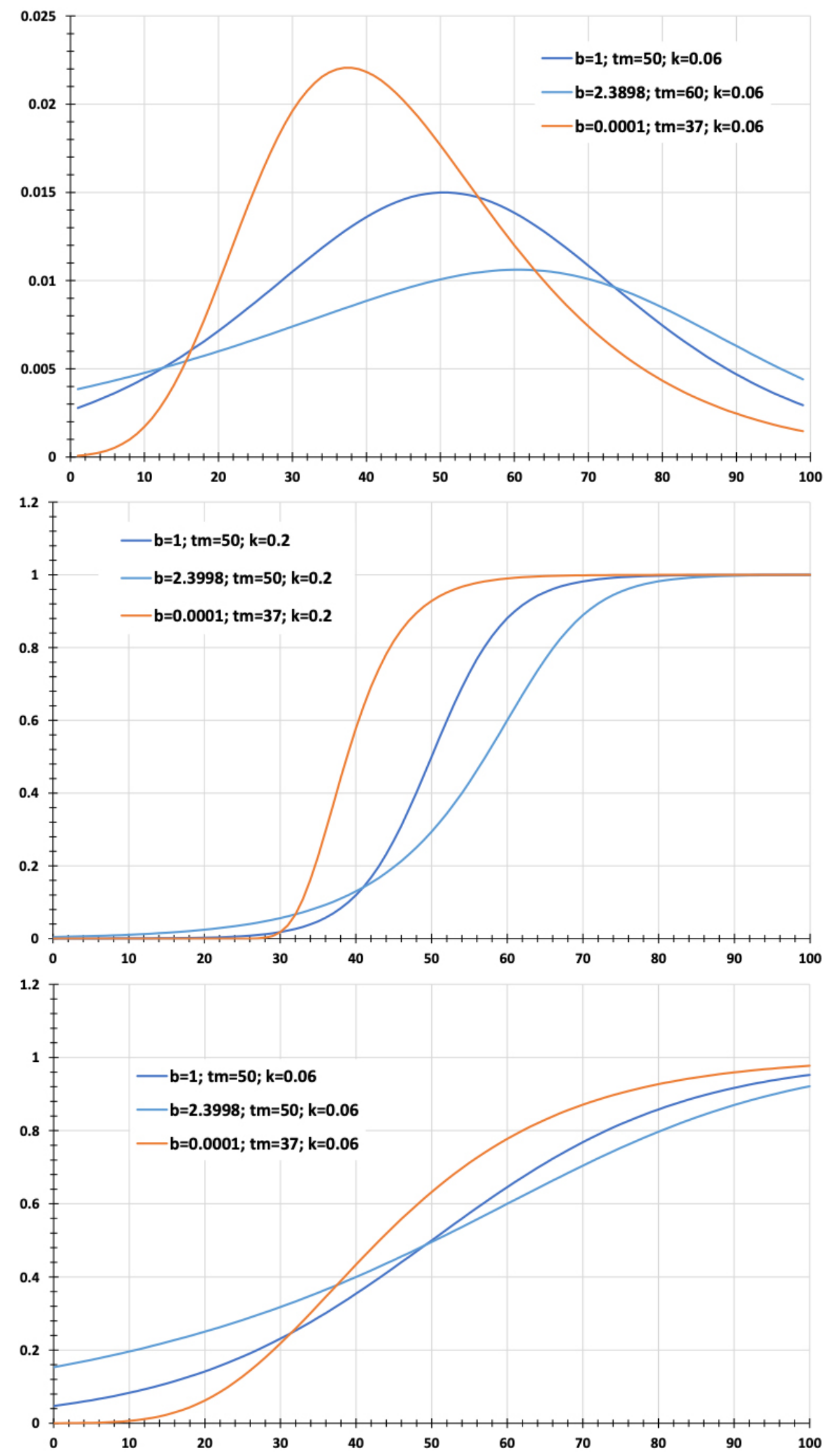

FIGURA 15. Curvas de produção anual (topo) e cumulada (base) ao longo de 100 anos simuladas com o modelo de Richards, considerando $U R R(t)=1$. Note-se a variação das características da curva em função dos valores tomados por $b, k$ e $t_{m}$. 
A grande vantagem decorrente da utilização do modelo de Richards prende-se com a possibilidade de confinar a taxa de crescimento, o que garante melhor aproximação à realidade porquanto dificilmente a actividade extractiva consegue crescer a taxas superiores a $5 \%$ durante longos períodos de tempo. Esta limitação, maioritariamente imposta por razões de natureza técnica, encontra ainda fundamento na impossibilidade de aceder simultaneamente à totalidade dos recursos conhecidos; daí também ser importante usar valores plausíveis para $U R R .0$ ajustamento dos valores históricos de produção (anual e cumulativa) às funções teóricas foi realizado atendendo às soluções produzidas pelo método dos mínimos quadrados.

\section{Resultados e implicações}

Como esperado, a modelação da produção futura é fortemente influenciada pelas taxas de crescimento vertiginosas que marcaram os últimos anos. É possível que parte dos valores declarados como "produção bruta anual" entre 2009 e 2016 correspondam a stocks de anos anteriores, transacionados apenas em condições favoráveis de mercado; contudo, não há forma de testar a plausibilidade deste pressuposto, pelo que os valores reportados pelos Serviços Geológicos Norte-Americanos foram tomados integralmente como resultado da produção realizada ano após ano. Nestas circunstâncias, os cenários indicados pelos modelos fornecem os elementos fundamentais para uma discussão sobre o abastecimento futuro do lítio, justificando investimentos a diferentes prazos na prospecção e pesquisa, exploração, tratamento e beneficiação de diferentes tipos de minérios. Vejamos porquê.

Fazendo uso de $U R R=53 \mathrm{Mt}$, facilmente se verifica que o pico de produção será atingido antes de 2050, qualquer que seja o modelo usado (FIGURA 16). A maior diferença reside na progressão da quantidade produzida anualmente em função do tempo; a suavização do crescimento antecipada pelo modelo de Verhulst prolonga o "tempo de usufruto" dos recursos.

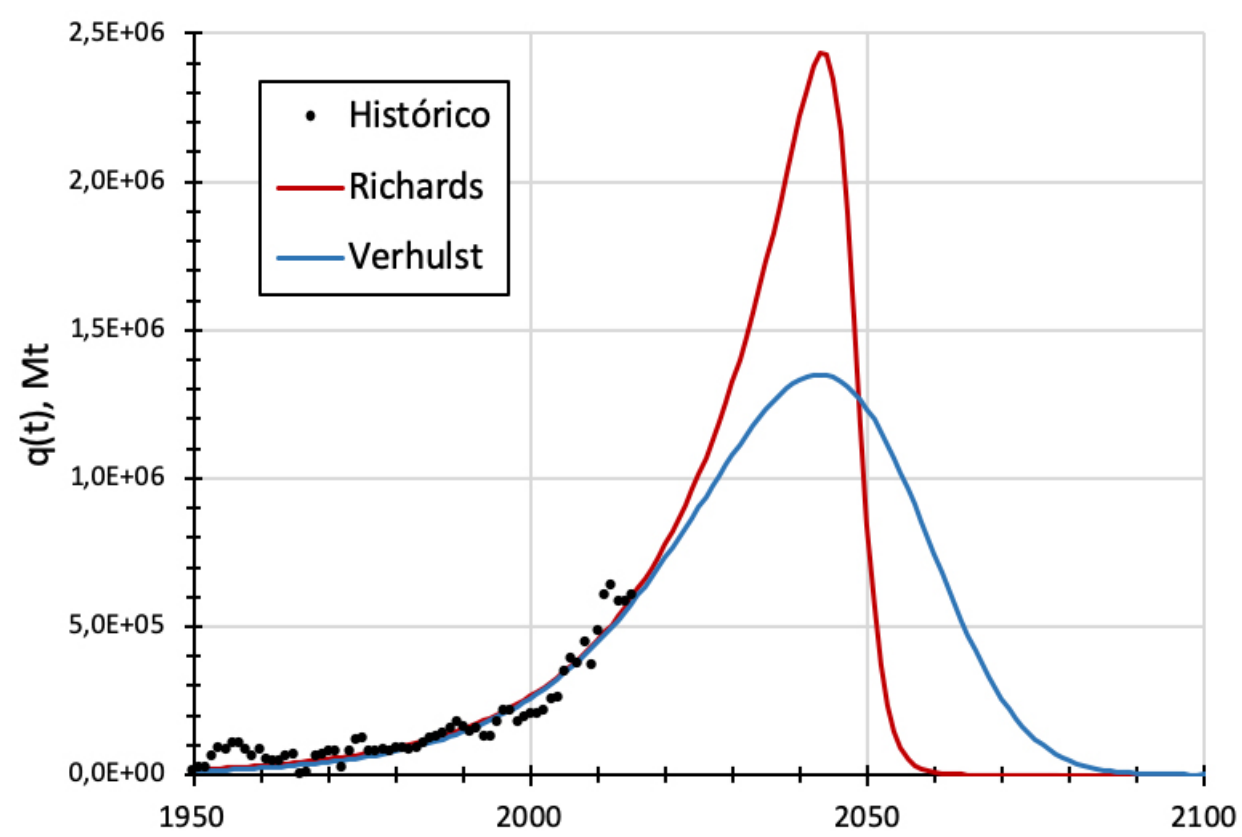

FIGURA 16. Evolução da produção anual tomando como referência $U R R=53 \mathrm{Mt}$ e os modelos gerais de Richards e de Verhulst. 
De forma consistente, mantendo-se o ritmo de produção dos últimos anos, as taxas de esgotamento dos recursos remanescentes progredirão rapidamente e sob valores alarmantes a partir de 2025 (FIGURA 17), demonstrando que os cenários de abastecimento futuro poderão estar fortemente comprometidos se (i) boa parte dos recursos que hoje conhecemos não forem viáveis por alguma razão (económica, ambiental ou social) e (ii) os esforços de prospecção forem descontinuados. As duas componentes complementam-se e são imprescindíveis.

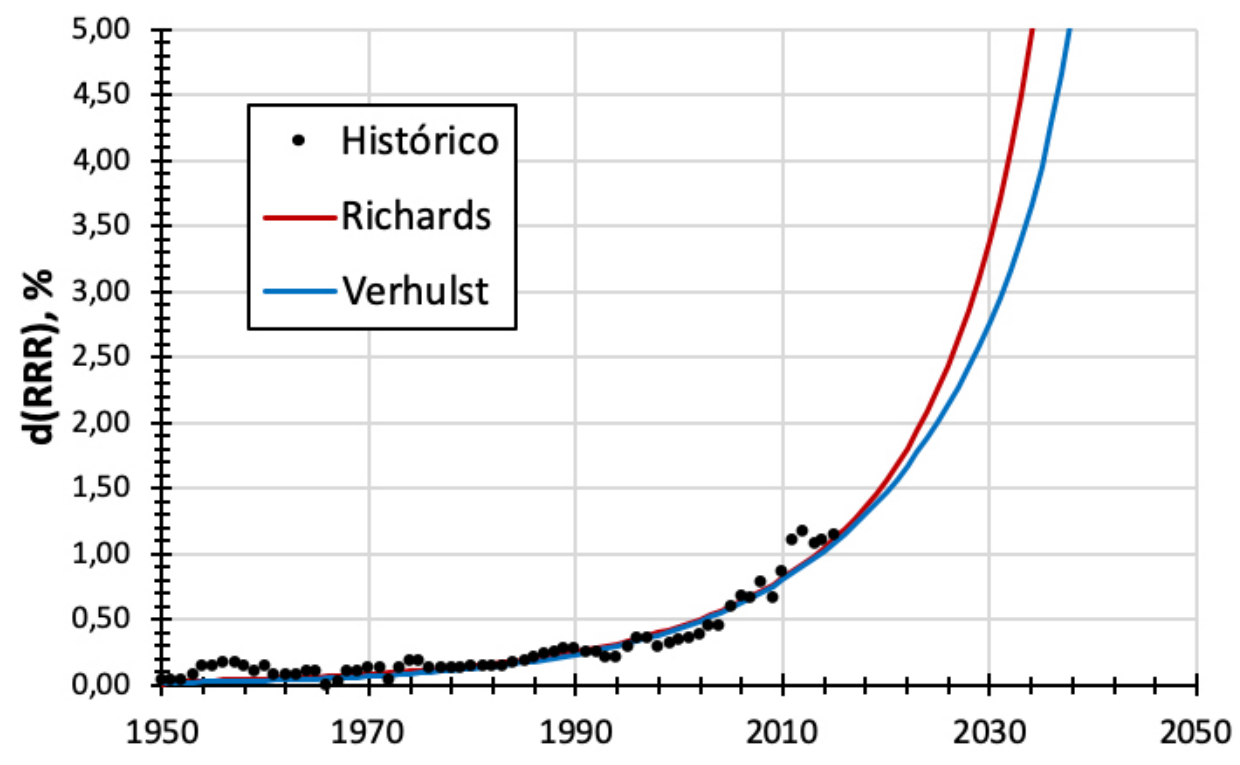

FIGURA 17. Evolução das taxas de esgotamento dos recursos remanescentes tomando como referência $U R R=53 \mathrm{Mt}$ e os modelos gerais de Richards e de Verhulst.

Outras simulações poderiam ser apresentadas, considerando valores mais elevados de $U R R$ e/ou diferentes limitações às taxas de aumento de produção, mas as diferenças ao nível dos resultados não seriam muito significativas. Neste âmbito, por exemplo, Sverdrup (2016) indica 2060 como o ano do pico de extracção, seguido de declínio suave, tomando para $U R R$ o valor de $74 \mathrm{Mt}$ (obtido pela adição de recursos com teor baixo ou ultra-baixo, hoje inviáveis em termos económicos). Adicionalmente, poder-se-ia admitir para breve o início de um novo ciclo de actividade mineira dedicado ao lítio pautado por características distintas das manifestadas pelo registo histórico disponível, em vez de considerar a evolução ao longo de um ciclo único; tal deslocaria o pico de produção para anos subsequentes. Contudo, qualquer tentativa neste sentido carece de suporte adicional em dados reais de produção, sendo preciso acompanhar a divulgação destes dados nos anos próximos para, de alguma forma, poder fundamentar o início deste eventual novo ciclo.

Independentemente das visões mais ou menos pessimistas quanto à segurança de abastecimento futuro, convém sublinhar de forma clara que estes modelos numéricos representam abordagens estáticas à realidade mineira, não considerando por exemplo as evoluções tecnológicas que influenciam os ritmos de produção e muito menos as variáveis de contexto (como a política fiscal ou de comércio) que podem consubstanciar alterações importantes na gestão das explorações minerais a diferentes escalas, assim como na disponibilização para o mercado internacional dos vários produtos gerados primariamente 
ou transformados/beneficiados. Para além de todos estes aspectos, incrementos consideráveis da reciclagem $L I B$ ou aparecimento de outras soluções competitivas, permitirão manter o provimento de lítio por mais tempo, retardando o momento em que o pico de produção será atingido e reduzindo a sua magnitude.

Compreender até que ponto podem existir recursos globais de lítio acima de $\approx 62 \mathrm{Mt}$ (valor máximo dos recursos globais estimados à data de 2019) ${ }^{51}$ implica ter uma ideia clara sobre a abundância relativa deste elemento químico nos sistemas terrestres. Nesta abordagem conceptual importa, uma vez mais, ter alguma prudência, pelo que tomaremos como referência apenas crosta continental e a sua porção acessível à actividade mineira comum (i.e. o primeiro quilómetro de profundidade). De acordo com o Tratado de Geoquímica, a abundância média do lítio neste contexto geológico cifra-se em torno de 41 ppm. Uma vez que:

$$
A_{i}^{U C}=\frac{M_{i}}{M_{U C}}
$$

onde $A_{i}^{U C}=$ abundância de um elemento $i$ na crosta superior, $M_{i}=$ Massa total do elemento $i$, e $M_{U C}=$ Massa total da crosta superior, obtém-se $M_{L i}^{U C}=17220000$ Mt, pois $M_{U C, 1 \text { kmprof. }}=4.2 \times 10^{17} t$. Tomando agora a abordagem de Menaker (1978), é possível estimar a média de $M_{L i}$ teoricamente concentrada em recursos minerais na crosta continental superior, $R_{i}$,

$$
R_{i}=10^{-2} b\left[\int_{\operatorname{In}\left(x_{i}^{\min }\right)}^{\operatorname{In}\left(\begin{array}{l}
\max \\
i
\end{array}\right)} e^{-\left(\operatorname{In} x_{i}^{\max }-\operatorname{In} x_{i}\right)} d \ln x_{i}\right] M_{U C} A_{i}^{U C}
$$

tendo em conta os valores máximos e mínimos dos teores de corte $\left(x_{i}\right)$ vulgarmente usados na exploração mineral. Com base nos registos de produção histórica, aquela expressão geral toma a forma

$R_{i}=10^{-2} v M_{U C} A_{i}^{U C} \approx 10^{-2}\left[(17 \pm 7) \times 10^{-4}\right] M_{U C} A_{i}^{U C} \approx 7.1 \times 10^{18} A_{i}^{U C}$

daqui resultando uma massa global de lítio potencialmente concentrada em anomalias geoquímicas passíveis de exploração de $M_{L i}^{R(U C)} \approx 29110 \mathrm{Mt}$. Se tomarmos agora os valores globais das reservas e recursos hoje conhecidos $(\approx 15 \mathrm{Mt}$ e $\approx 62 \mathrm{Mt}$, respectivamente), verifica-se que não existem evidências firmes para a exaustão física, havendo certamente espaço para novas descobertas, desde que se mantenham elevados os níveis de investimento em prospecção e pesquisa mineral ${ }^{72}$.

\section{Posicionamento da União Europeia face ao lítio}

Em 2016, a problemática do lítio na UE podia ser sumarizada em três linhas fundamentais de evidência: (i) o consumo representava $\approx 24 \%$ da procura global, mas a produção interna não ia além de $2 \%$ do montante apurado à escala mundial (todo ele oriundo de pequenas explorações em território português, tanto quanto é possível aquilatar com base nos dados consultados); (ii) a UE afirmava-se como o maior mercado de EV e em alguns dos seus Estados-Membros (e.g. Noruega) estes veículos já significavam mais de $20 \%$ dos novos 
registos anuais; e (iii) as estratégias a curto-médio prazo divulgadas por grandes grupos industriais europeus, consistentes com objectivos e indicadores de política pública para os setores da mobilidade eléctrica e do armazenamento de energia gerada em sistemas tecnologicamente sustentáveis equipando parques residenciais e/ou grandes redes de distribuição, apontavam para aumentos de consumo de lítio que ampliariam consideravelmente a dependência da UE de produtores estrangeiros. A percepção de que as estratégias desenhadas para o futuro poderiam ficar reféns da disponibilidade de lítio nos mercados internacionais e da volatilidade dos preços praticados levou a alterações consideráveis da estratégia europeia em curto intervalo de tempo. A European Battery Alliance representa o corolário mais visível de um lato conjunto de medidas que pretendem desenvolver de forma adequada a cadeia de valor associada às baterias recarregáveis. De acordo com o relatório de 2019 da Benchmark Mineral Intelligence a estratégia delineada visa, entre outros objectivos, aumentar rapidamente a produção europeia de LIB, tornando-a competitiva e passando de $20 \mathrm{GWh}$ (2018) para valores em torno de $143 \mathrm{GWh}$ em 2023 e 304 GWh em 2028. Estes propósitos ambiciosos exigem cuidados acrescidos com o incremento da produção doméstica de lítio (dos concentrados minerais aos produtos litiníferos transformados), para além da necessidade de assegurar o cumprimento integral de numerosas variáveis relacionadas com a tecnologia LIB (da manufactura à reciclagem). Neste sentido, é oportuno perguntar quais as medidas tomadas pela UE no sentido de aumentar a produção doméstica de lítio (mitigando eventuais disrupções de abastecimento)? Foram estes aspectos tidos em consideração no último exercício sobre a criticalidade das matérias-primas minerais para a economia europeia? Qual o contributo que Portugal poderá dar neste âmbito?

A última revisão da lista de matérias-primas críticas para a UE manteve a abordagem estática dos exercícios anteriores, não incorporando indicadores sobre tendências de consumo e/ou de alteração dos processos industriais. Esta revisão procurou ainda reduzir o impacto sobre o risco de abastecimento invocando contributos potenciais resultantes da reciclagem e da substituição; em muitos casos, porém, as fracções imputadas a estas duas fontes alternativas pecaram por excessivas, acabando por influenciar negativamente os resultados finais. Ou seja, para muitas das matérias-primas analisadas, os valores que expressam a importância económica $(E I)$ e/ou o risco de abastecimento $(S R)$ carecem de demonstração adicional ${ }^{27}$.

Este não é o local adequado para discutir as premissas usadas no modelo aprovado pela UE para a análise da criticalidade ${ }^{72}$. Será, contudo, importante perceber que a recolha de dados e demais informação para efeitos de cálculo naquele exercício tomou como referência um quadro que reflectia apenas a "utilização tradicional do lítio" na Europa, onde o setor das baterias valia $\approx 1 \%$ do total consumido entre 2010-2014 (FIGURA 18). Consequentemente, os resultados obtidos consolidaram a ideia de que não havia importância económica acrescida para o lítio na UE e que o seu risco de abastecimento estava no limiar da "linha de perigo". Esta é uma conclusão legítima face aos resultados numéricos obtidos, mas bastante desfasada da realidade e, sobretudo, das perspectivas futuras ${ }^{60,42}$. 


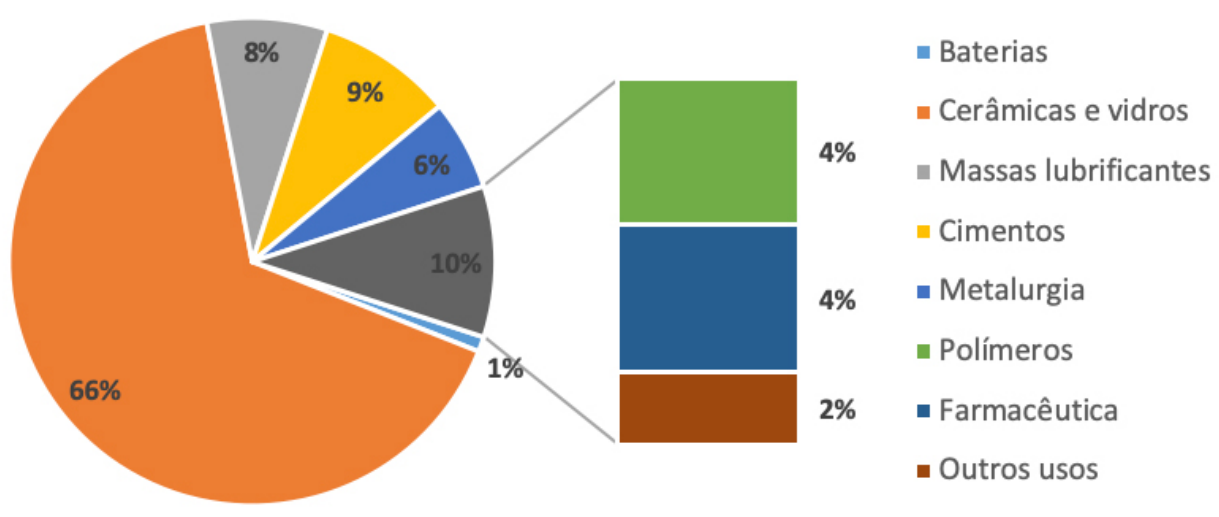

FIGURA 18. Repartição do consumo de lítio na UE considerando os valores médios de cada subsetor referentes ao período 2010-2014. Informações adicionais podem ser obtidas em “Bio Intelligence Service (2015). Study on Data for a Raw Material System Analysis: Roadmap and Test of the Fully Operational MSA for Raw Materials - Final Report. Prepared for the European Commission, DG GROW." pp. 41-43.

A concretização das estratégias anunciadas por alguns dos principais grupos industriais europeus em conjunto com a implementação de várias políticas públicas, com impacto nomeadamente nos setores dos transportes e da energia, irá alterar de forma radical os fluxos do lítio na $U^{9}$. Esta alteração aumentará necessariamente a dependência da UE de quantitativos importados, a menos que a produção doméstica cresça de forma assinalável a curto prazo. Não se antecipam grandes modificações ao nível dos "consumidores tradicionais europeus" mas, tal como assinalado anteriormente, espera-se que o setor das baterias cresça bastante. Esta expectativa será contudo contrariada se os principais consumidores potenciais (em particular a "nova" indústria automóvel) deslocarem os seus futuros centros de produção de baterias e/ou de montagem EV para territórios fora do espaço europeu. É bem possível que na(s) próxima(s) década(s) hajam novidades quanto à reciclagem de baterias e à implementação de infraestruturas adequadas à recolha e redistribuição destes produtos; mas este é um caminho que só agora começa a ser desbravado. Até ser possível garantir percentagens expressivas de reciclagem toda a "economia do lítio" manterá forte dependência da produção primária e, atendendo às razões atrás explicitadas, orientar-se-á preferencialmente para sistemas pegmatíticos análogos aos que existem no território português.

\section{Situação em Portugal}

Portugal é um dos maiores produtores de lítio à escala mundial e, sem qualquer margem para dúvida, o único que à escala da UE mantém produção activa e com imenso potencial para crescer. Com efeito, a meritória posição de Portugal no ranking de produtores mundiais mais do que reflectir conhecimento sistemático dos recursos litiníferos nacionais, traduz apenas o que tem sido extraído (na maior parte dos casos de forma intermitente) de alguns campos pegmatíticos para abastecer o subsetor das cerâmicas (e vidro?) em função das solicitações de mercado. Muito há por fazer, designadamente no que diz respeito à delimitação tridimensional dos principais sistemas pegmatíticos reconhecidos em afloramento e, assim, à demonstração da continuidade de tonelagem e de teor necessária para justificar os estudos de viabilidade que determinarão o cálculo de reservas. De forma muito simples: conhecemos razoavelmente a expressão superficial de vários siste- 
mas pegmatíticos, mas a sua extensão e caracterização em profundidade é praticamente desconhecida na maioria dos casos. No levantamento realizado pelo LNEG em $2010^{33}$, o potencial moderado assinalado para o lítio consubstanciava-se na estimativa global de recursos em torno de $106 \mathrm{kt} \mathrm{Li}$. Dados mais recentes ${ }^{20}$ indicam valores de $306 \mathrm{kt}$ Li para o conjunto dos recursos reconhecidos em Portugal ( $\approx 71$ Mt pegmatitos litiníferos), embora as reservas não excedam $53 \mathrm{kt} \mathrm{Li}$. É bem possível que estes valores estejam subestimados, mas só o saberemos após conclusão dos trabalhos de avaliação em curso para algumas áreas potenciais. Acrescem a estes indicadores os resultados positivos que eventualmente venham a surgir dos vários projectos de prospecção e pesquisa mineral formalmente instruídos desde 2016, mas que aguardam decisão administrativa favorável para avançar; estes projectos estendem-se por uma área global de $\approx 2500 \mathrm{~km}^{2}$ e contemplam um investimento de $\approx 4 \mathrm{M}^{20}$.

\section{Distribuição dos recursos conhecidos}

Não é objectivo deste trabalho discorrer sobre os vários sistemas pegmatíticos com potencial litinífero até ao presente reconhecidos em Portugal. Para o efeito, muitas são as referências bibliográficas que podem ser consultadas, fornecendo informações relevantes sobre as características morfológicas e composicionais dos principais campos pegmatíticos localizados em diferentes setores das regiões norte e centro do País: Serra d'Arga; Seixoso-Vieiros; Barroso-Alvão; Almendra; Barca d'Alva-Escalhão; Massueime; Guarda (in-

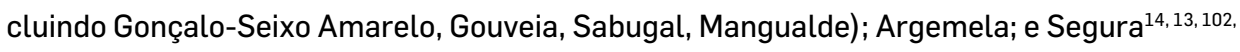
$61,62,12,100,101,64,31,103,2,3,81,69,82,70,65,71,63,86,105$.

A informação geológica acumulada ao longo de várias décadas de estudos é bastante diversa e de boa qualidade, embora na maioria dos casos se limite aos domínios aflorantes dos sistemas pegmatíticos. Tal não impede, contudo, a sua utilização como ponto de partida para novas pesquisas; pelo contrário. E em boa medida esta é a razão pela qual o território nacional tem suscitado a atenção de diversas companhias. Este trabalho de prospecção e pesquisa mineral revela-se particularmente crítico pois, salvas raras excepções, não houve até ao momento capacidade de investimento suficiente para investigar a extensão em profundidade dos alvos identificados à superfície (o número de sondagens efectuado fica muito aquém do desejável e não cobre a totalidade das áreas) e, muito menos, suportar os custos necessários para proceder à análise fidedigna das distribuições espaciais de teores.

Parte significativa dos recursos pegmatíticos nacionais com interesse litinífero inclui lepidolite como principal fase portadora e, nas últimas décadas, foram estes os que alimentaram o essencial da produção (sempre superficial) realizada sobretudo na região de Gonçalo-Seixo Amarelo. Outros sistemas pegmatíticos (e.g. Serra de Arga e Barroso-Alvão) incluem quantidades consideráveis de espodumena ( \pm petalite), sendo por isso mais apelativos em termos económicos mercê do conhecimento tecnológico existente sobre o tratamento e beneficiação desta matéria-prima mineral visando a produção de carbonato ou hidróxido de lítio após separação e processamento químico. Existem ainda vários exemplos de sistemas pegmatíticos (e.g. Argemela, Segura) em que as fases litiníferas abundantes integram a série ambligonite-montebrasite cuja caracterização detalhada deve igualmente ser realizada no sentido de averiguar a viabilidade da sua exploração e subsequente beneficiação. Acresce referir que, em conformidade com os resultados experimentais obtidos até 
ao momento ${ }^{118}$, boa parte dos minérios de lítio portugueses são passíveis de valorização tecnológica através da aplicação simples ou combinada de processos de separação recorrendo a meios densos, separadores ópticos e flutuação por espumas. A selecção adequada dos processos de cominuição e separação, necessariamente precedida por caracterização petrográfica e mineralógica detalhada, permitirá garantir níveis de eficiência elevados com consumos parcimoniosos de água e energia. Adicionalmente, a implementação de medidas complementares, tornará possível aproveitar elevado número de coprodutos ou subprodutos, reduzindo significativamente os volumes de rejeitados (resíduos).

\section{Cenários futuros}

Em Portugal, a situação presente no que respeita à produção de concentrados minerais litiníferos pode ser ilustrada de forma simples pelo esquema patente na FIGURA 19, o qual pretende representar a manutenção de uma exploração não continuada de concentrados lepidolíticos a partir de recursos mal caracterizados em profundidade, canalizando o essencial da produção para a indústria cerâmica ( \pm vidreira) nacional. As quantidades exportadas são relativamente pequenas e bastante variáveis no tempo; do mesmo modo que a incorporação de resíduos das indústrias cerâmica e vidreira nos concentrados a usar como fundentes é manifestamente exígua (tanto quanto é conhecido publicamente).

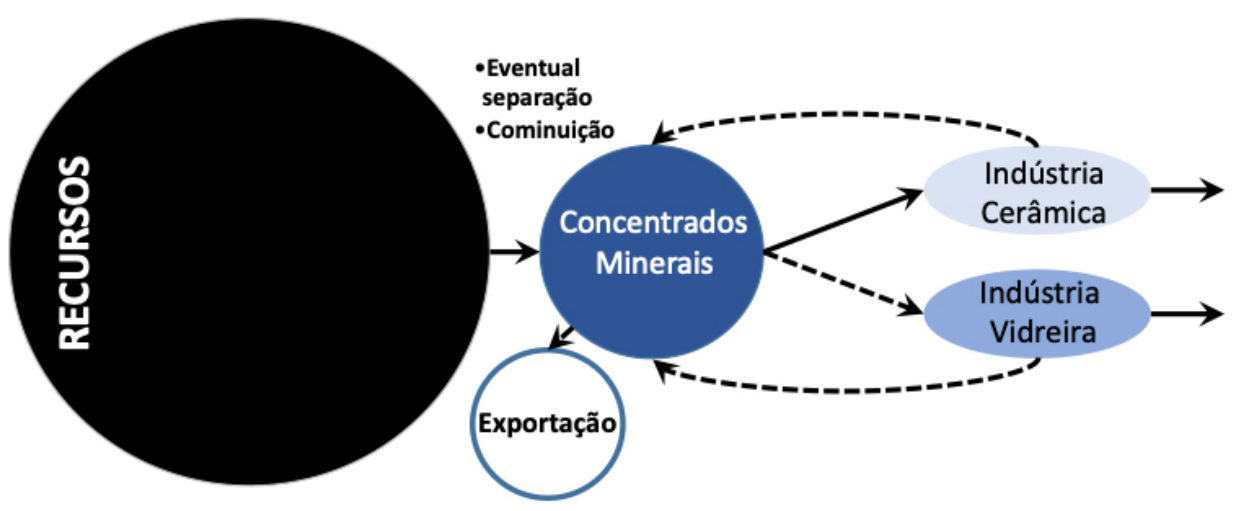

FIGURA 19. Representação esquemática dos fluxos materiais suporte à incipiente cadeia de valor existente em Portugal para os minérios de lítio.

Deste modo, um dos principais eixos de consolidação/melhoria a curto prazo consiste na optimização desta componente do ciclo, incrementando a exportação para os setores da cerâmica/vidro/cimento e reduzindo o descarte final através da implementação de medidas de reutilização e reciclagem de resíduos. Este eixo de consolidação/melhoria será tanto mais bem-sucedido quanto maior for o conhecimento sobre os recursos e reservas existentes no País, permitindo a gestão integrada destes capitais naturais e alimentando a produção de concentrados de maior valor comercial e, consequentemente, elevada possibilidade de exportação (FIGURA 20). Neste contexto, a determinação da abundância relativa das fases minerais litiníferas e sua composição química reveste-se de particular importância na identificação de reservas com alto ou baixo teor. 0 valor limite usado na separação de minérios de alto e baixo teor depende de vários factores de mercado e das soluções tecnológicas disponíveis para a valorização rentável dos concentrados minerais explorados; presentemente, para sistemas pegmatíticos, reservas com teores de $\mathrm{Li}_{2} \mathrm{O}$ acima de $1 \mathrm{wt} \%$ são consideradas de alto teor, em particular se ricas em espodumena ( \pm petalite). 


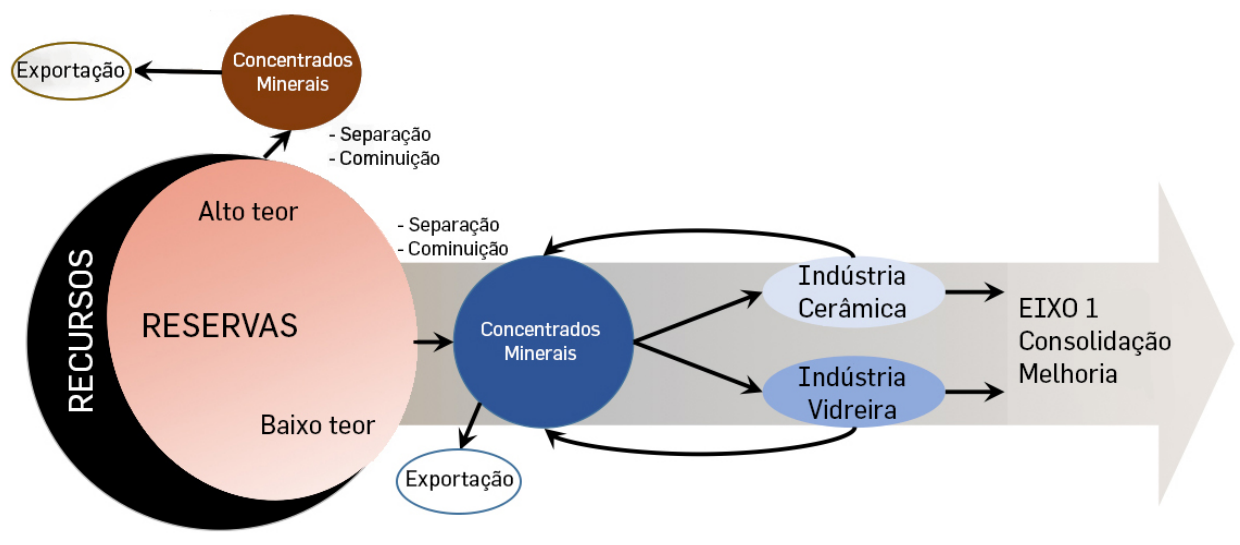

FIGURA 20. Representação esquemática dos fluxos materiais que, de forma optimizada, poderiam suportar uma cadeia de valor modesta para os minérios de lítio portugueses. Este eixo de desenvolvimento pode ser implementado em curto intervalo de tempo. Presentemente, minérios com alto teor em sistemas pegmatíticos apresentam valores de $\mathrm{Li}_{2} \mathrm{O}$ acima de 1 wt\%, com frequência enriquecidos em espodumena ( \pm petalite).

Contudo, se devidamente contextualizada numa visão de desenvolvimento industrial a maior prazo e de incontestável subida na cadeia de valor, a produção de muitos destes concentrados minerais de maior teor poderá sustentar (e justificar) a instalação de algumas unidades de tratamento e beneficiação da matéria-prima mineral transformando-a em hidróxido ou carbonato de lítio. Este percurso sustenta a criação de um segundo eixo de desenvolvimento, projectando a produção nacional para patamares verdadeiramente competitivos a nível internacional e contribuindo de forma indelével para a redução da dependência das importações por parte da EU (FIGURA 21).

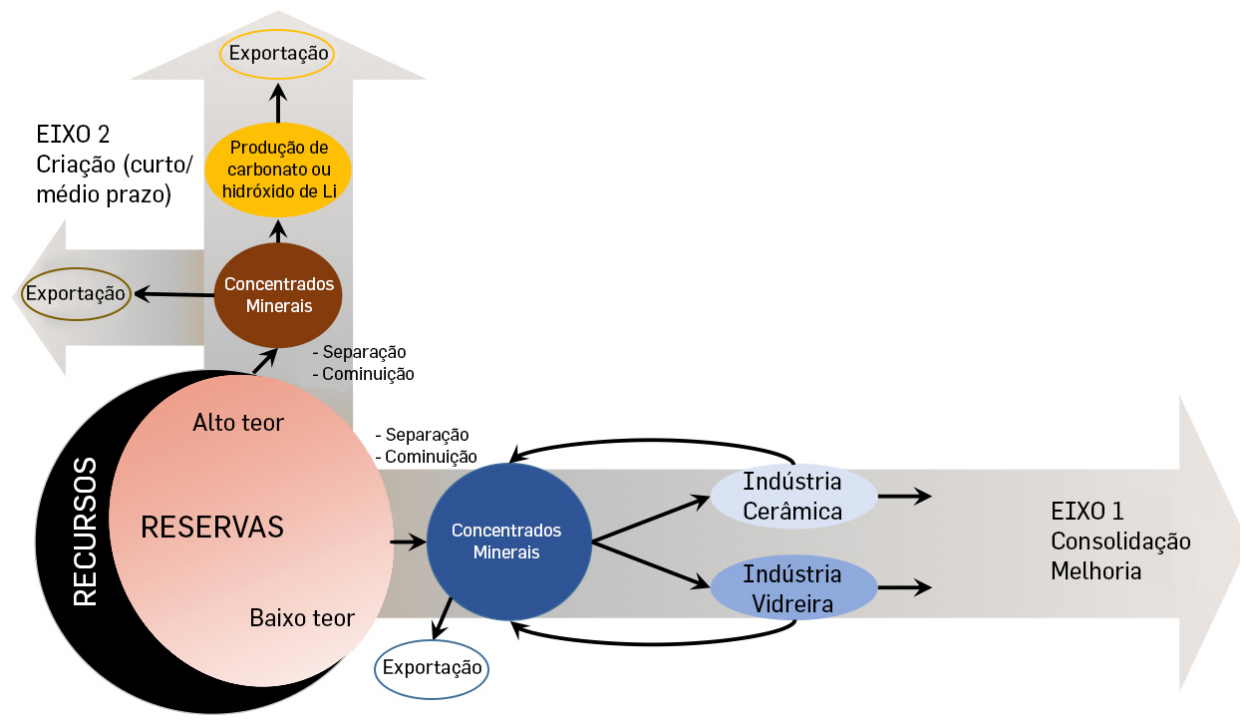

FIGURA 21. Representação esquemática dos fluxos materiais que poderiam suportar uma cadeia de valor competitiva para os minérios de lítio portugueses e $L I B$, consolidando a curto-médio prazo um segundo eixo de desenvolvimento orientado para a produção de hidróxido ou carbonato de lítio.

Mas a visão de desenvolvimento integrado pode ir um pouco mais longe, considerando ainda a importância acrescida que o sector automóvel tem no PIB nacional, a necessidade cada vez maior de armazenar os "excedentes" de energia gerados em períodos de pico (nomeadamente via sistemas eólicos) e a expansão crescente (e projectada) para 
os subsectores da informática/digital. Significa isto a criação a médio-longo prazo de um terceiro eixo que se alimenta de boa parte dos derivados de lítio produzidos na segunda linha de desenvolvimento para gerar diferentes tipos de baterias recarregáveis, subsequentemente canalizadas para os sectores referidos. A manufactura destas baterias exige outros elementos químicos que não o lítio, exigindo aumentos de importação facilmente compensados pela importante subida na cadeia de valor que representa o fabrico de LIB. Adicionalmente, a implementação cuidada (planificada) deste 30 eixo (FIGURA 22) permitiria por certo estimular as linhas de investigação necessárias à pesquisa das melhores soluções para incrementos de reciclagem de lítio e LIB, contribuindo para a redução dos impactes da exploração dos recursos primários.

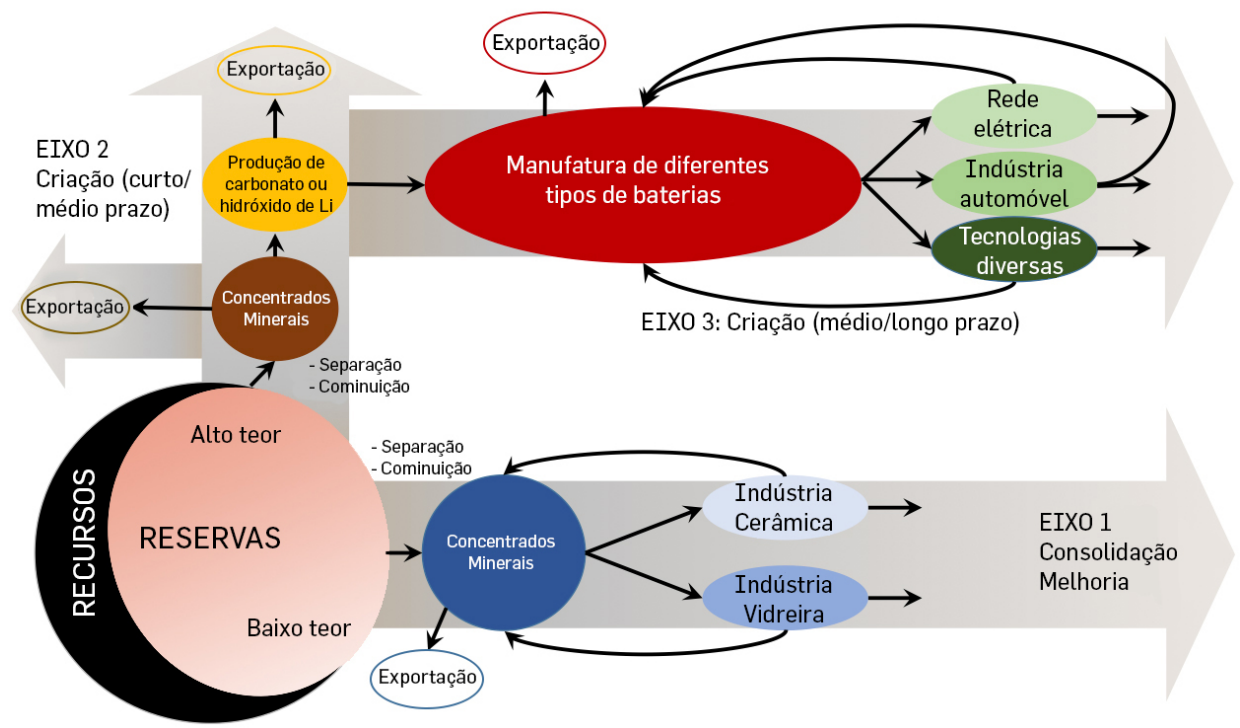

FIGURA 22. Representação esquemática dos fluxos materiais que poderiam suportar uma cadeia de valor global para os minérios de lítio portugueses e LIB, consolidando três eixos complementares de desenvolvimento implementáveis em diferentes escalas de tempo.

No seu todo, a visão geral gera um cenário que pode (e deve) ser implementado (e monitorizado) em sucessivas etapas, concorrendo para um largo conjunto de objectivos com evidente importância económica e social, mas também ambiental. A subida na cadeia de valor mineral, gerando maior riqueza e emprego qualificado, configura assim um passo importante para o desenlace de diversas transformações em cascata que acabam por ser decisivas à: (i) consolidação da mobilidade eléctrica; (ii) gestão sustentável da energia gerada via eólica ou fotovoltaica (em meio residencial ou em rede); (iii) generalização da sociedade digital; (iv) promoção de estímulos para o incremento da reciclagem/reutilização de produtos contendo lítio ou seus derivados, reduzindo a pressão sobre os recursos primários. Importa, porém, não esquecer que na base de todas estas transformações está, e continuará a estar por muito tempo, a prospecção e pesquisa mineral cujas actividades devem ser devidamente apoiadas/estimuladas e, sobretudo, integradas numa visão de desenvolvimento estratégico para a indústria mineira em Portugal que abarque outras matérias-primas minerais para além das litiníferas. 


\section{Conclusões}

Muitos dos grandes desafios que hoje se colocam à Sociedade requerem mudanças significativas na forma como consideramos e usufruímos os recursos naturais que se distribuem pela Litosfera, Hidrosfera, Biosfera e Atmosfera. Contudo, o conhecimento disponível sobre estes recursos (sua constituição, dinâmica e articulação em diferentes escalas de tempo e espaço) e o modo como eles se articulam com os stocks e fluxos de energia e matéria que suportam a economia física (em que assenta a civilização Humana) ainda é bastante fragmentado, apresentando numerosas lacunas. Por isso, a mitigação apressada de alguns problemas gera frequentemente outras pressões nem sempre antecipadas e/ou cuja magnitude acaba por se revelar mais severa do que o previsto.

Desenvolvimentos políticos recentes sobre a descarbonização dos setores de energia e transportes têm concorrido para a adopção rápida e generalizada de soluções tecnológicas que, entre outras componentes, usam baterias recarregáveis de iões de lítio. Como resposta a esta evolução célere, a percentagem de lítio destinada à manufactura de baterias tem vindo a crescer de forma exponencial, podendo atingir em 2026 cerca de $64 \%$ do valor estimado para a demanda global de lítio no mercado ( $\approx 1 \mathrm{Mt} L C E)$. As projecções existentes indicam ainda que as baterias de iões de lítio deverão prevalecer no mercado até 2050 e, embora sejam esperados avanços consideráveis na reciclagem destes equipamentos, não se afigura plausível que a taxa de recuperação de lítio por esta via seja suficiente para suprir as aguardadas necessidades de consumo. Importa, assim, garantir condições mínimas de segurança no abastecimento futuro de lítio, bem como de muitas outras matérias-primas minerais imprescindíveis ao uso generalizado das referidas soluções tecnológicas ou de outras que as venham substituir.

Vários estudos publicados nos últimos anos sobre a disponibilidade de recursos de lítio concluem não haver razões para grandes preocupações. Ou seja, os recursos identificados aparentam ser suficientes para responder à procura crescente que se antecipa como certa para as próximas décadas. Algumas das evidências apresentadas nestes estudos são, contudo, discutíveis, não tendo em devida consideração os numerosos factores que determinam a delimitação de reservas (i.e. a componente economicamente explorável dos recursos), nem as condicionantes de natureza ambiental e social que influenciam decisões administrativas e financeiras sobre novos empreendimentos de mineração da matéria-prima mineral e sua transformação em compostos de lítio utilizáveis nas diferentes fileiras industriais. Deste modo, importa manter níveis altos de investimento em projectos promissores de prospecção e pesquisa mineral, análogos a muitos dos que já começaram ou estão em vias de início em Portugal. Este é um passo incontornável no longo processo que culminará na delimitação, inventariação e caracterização dos recursos de lítio existentes no País. Alguns destes recursos poderão vir a ser explorados, caso os estudos de viabilidade económica e ambiental assim o permitam. E se tal acontecer será sempre desejável que o projecto mineiro suba na cadeia de valor, sendo acompanhado pela construção das infraestruturas necessárias ao tratamento e beneficiação dos produtos minerais primários. A lógica subjacente a este desenvolvimento terá de almejar a edificação de núcleos industriais tecnologicamente evoluídos e social/ambientalmente responsáveis, capazes e competitivos, integrando por direito próprio a recém-criada European Battery Alliance. 


\section{Agradecimentos}

Muitas das ideias explicitadas ao longo deste texto representam o corolário de discussões mantidas com numerosos Colegas de diferentes áreas científicas e tecnológicas, no mundo académico e empresarial. Foram igualmente decisivos os estimulantes desafios colocados pelos estudantes de pós-graduação com quem tive o privilégio de trabalhar na última década. A todos se agradecem os esclarecimentos prestados, questões suscitadas e incentivos concedidos. $\mathrm{O}$ autor agradece ainda o suporte da FCT através dos projectos UID/GEO/50019/2019 e UIDB/50019/2020 - Instituto Dom Luiz (IDL).

\section{REFERÊNCIAS}

${ }^{1}$ AHMED, S., et al., Cost and energy demand of producing nickel manganese cobalt cathode material for lithium ion batteries. Journal of Power Resources, 342: 733-740. 2017.

${ }^{2}$ ANTUNES, I., et al., Geochemistry of minerals from Li-bearing granitic aplite-pegmatite veins of Segura area (Castelo Branco, Portugal). Mem. no 8, Granitic Pegmatites: The State of the Art (T. Martins \& R. Vieira, Eds.), Porto, pp. 28-29. 2007.

${ }^{3}$ ANTUNES, I.M.H.R., et al.,. Mineralogia dos filões aplito-pegmatíticos litiníferos da região de Segura. Ciências Geológicas - Ensino e Investigação e sua História, Vol. I, Capítulo I - Cristalografia e Mineralogia I 3. 2010.

${ }^{4}$ AUER, H. \& HAAS, R., On integrating large shares of variable renewables into the electricity system. Energy, 115, 1592-1601. 2016.

${ }^{5}$ BALLINGER, B., et al., The vulnerability of electric vehicle deployment to critical mineral supply. Applied Energy, 255, 113844. 2019.

${ }^{6}$ BAUMANN, M., et al., $\underline{C O}_{2}$ footprint and life-cycle costs of electrochemical energy storage for stationary grid applications. Energy Technology, 5, 1071-1083. 2017.

${ }^{7}$ BERNARDES, A.M., et al., Recycling of batteries: a review of current processes and technologies. Journal of Power Sources, 130, 291-298. 2004.

${ }^{8}$ BERNHART, W., The lithium-ion battery value chain - status, trends and implications. In: Pistola, G. (Ed.) Lithium-ion Batteries. Elsevier, pp. 553-565. 2014

${ }^{9}$ BIO by Deloitte, Study on Data for a Raw Material System Analysis: Roadmap and Test of the Fully Operational MSA for Raw Materials. Prepared for the European Commission, DG GROW. 2015.

${ }^{10}$ British Geological Survey, Lithium Profile. 2016.

${ }^{11}$ CALVERT, G., et al., Recovery of metals from waste lithium ion battery leachates using biogenic hydrogen sulfide. Minerals, 9, 563. 2019.

${ }^{12} \mathrm{CHAROY}, \mathrm{B}$. \& NORONHA, F., A multistage model for growth of a rare element, volatile rich microgranite: the example of Argemela (Portugal). Journal of Petrology, 37, 73-94. 1995.

${ }^{13}$ CHAROY, B., et al., Spodumene petalite eucryptite: Mutual relationships and pattern of alteration in Li-rich aplite-pegmatite dykes from northern Portugal. Canadian Mineralogist, 39, 729-746. 2001.

${ }^{14} \mathrm{CHAROY}, \mathrm{B} .$, et al., The crystal chemistry of spodumene in some granitic aplite-pegma tite of Northern Portugal: a comparative review. Canadian Mineralogist, 30, 639-651. 1992.

${ }^{15} \mathrm{CHEN}, \mathrm{X}$., et al., Separation and recovery of valuable metals from spent lithium batteries: simultaneous recovery of $L i$ and Co in a single step. Separation and Purification Technology, 210, 690-697. 2019.

${ }^{16} \mathrm{CHOUBEY}$, P.K., et al., Advance review on the exploitation of the prominent energy-storage element: lithium. Part I: from mineral and brine resources. Minerals Engineering, 89, 119-137. 2016.

${ }^{17}$ CHRISTMANN, P., et al., Global lithium resources and sustainability issues. In: Lithium Process Chemistry. Elsevier, pp. 1-40. 2015.

${ }^{18}$ DEETMAN, S., et al., Scenarios for demand growth of metals in electricity generation technologies, cars, and electronic appliances. Environmental Science \& Technology, 52, 4950-4959. 2018.

${ }^{19}$ DEWOLF, J., et al., Recycling rechargeable lithium ion batteries: critical analysis of natural resource savings. Resources, Conservation and Recycling, 54, 229-234. 2010.

${ }^{20}$ DINIS, P. \& HORGAN, S., Informação estatística sobre produção de recursos minerais contendo lítio. Evolução no período de 1998 a 2017. Boletim de Minas, 52 - Edição Especial - Lítio - 2017-2018, 125-133. 2018.

${ }^{21}$ DIVYA, K.C. \& ØSTERGARD, J., Battery energy storage technology for power systems - an overview. Electric Power Systems Research, 79, 511-520. 2009.

${ }^{22}$ EBENSPERGER, A., et al., The lithium industry: its recent evolution and future prospects. Resources Policy, 30, 218231. 2005.

${ }^{23} \mathrm{EGBUE}$, O. \& LONG, S., Critical issues in the supply chain of lithium for electric vehicle batteries. Engineering Management Journal, 24, 52-52. 2012.

${ }^{24}$ ELSHKAKI, A. \& GRAEDEL, T.E., Dynamic analyses of the global metals flows and stocks in electricity generation technologies. Journal of Cleaner Production, 59, 260-273. 2013.

${ }^{25}$ ELWERT, T., et al., Current developments and challenges in recycling of key components of (hybrid) electric vehicles. Recycling, 1, 25-60. 2016.

${ }^{26}$ EUROPEAN COMMISSION, Energy: roadmap 2050. Publications Office of the European Union, Luxembourg, pp. 20. 2012. 
${ }^{27}$ EUROPEAN COMMISSION, Study on the review of the list of critical raw materials. European Commission. 2017. ${ }^{28}$ EUROPEAN COMMISSION, Report on raw materials for battery applications. SWD, 245/2 Final. European Commission. 2018.

${ }^{29}$ EUROPEAN COMMISSION, Forth report on the state of the energy Union. COM, 175 Final. European Commission. 2019. ${ }^{30}$ EUROPEAN COMMISSION, Report on the implementation of the strategic action plan on batteries: building a strategic battery value chain in Europe. COM, 176 Final. European Commission. 2019.

${ }^{31}$ FARINHA, J. \& LIMA, A., Estudo dos filões aplitopegmatíticos litiníferos da Região do Barroso-Alvão (Norte de Portugal). Estudos, Notas e Trabalhos, 42, 3-50. 2000.

${ }^{32}$ FASEL, D. \& TRAN, M.Q., Availability of lithium in the context of future D-T fusion reactors. Fusion Engineering and Design, 75-79, 1163-1168. 2005.

${ }^{33}$ FILIPE, A., et al., Recursos Minerais. O Potencial de Portugal. LNEG, Lisboa, pp.74. 2010.

${ }^{34}$ FLEXER, V., et al., Lithium recovery from brines: a vital raw material for green energies with a potential environmental impact in its mining and processing. Science of the Total Environment, 639, 1188-1204. 2018.

${ }^{35}$ GAINES, L., et al., Life-cycle analysis for lithium-ion battery production and recycling. 90th Annual Meeting of the Transportation Research Board, Washington D.C., 11-3891. USA. 2011.

${ }^{36}$ GARRETT, D.E., Handbook of lithium and natural calcium chloride, their deposits, processing, uses and properties. Elsevier Academic Press, pp. 476. 2004.

${ }^{37}$ GERSSEN-GONDELACH, S.J. \& FAAIJ, A.P.C., Performance of batteries for electric vehicles on short and longer term. Journal of Power Sources, 212, 111-129. 2012.

${ }^{38}$ GIELEN, D., et al., Climate and energy challenges for materials science. Nature Materials, 15, 117-120. 2016.

${ }^{39}$ GROSJEAN, C., et al., Assessment of world lithium resources and consequences of their geographic distribution on the expected development of the electric vehicle industry. Renewable and Sustainable Energy Reviews, 16, 1735-1744. 2012.

${ }^{40}$ GRUBER, P.W., et al., Global lithium availability: a constraint for electric vehicles?. Journal of Industrial Ecology, 15 , 760-775. 2011.

${ }^{41}$ HADJIPASCHALIS, I., et al., Overview of current and future energy storage technologies for electric power applications. Renewable and Sustainable Energy Reviews, 13, 1513-1522. 2009.

${ }^{42}$ HANDLEY, P., Raw materials for battery value chain. European Commission. Directorate-General for Internal Market, Industry, Entrepreneurship and SME's (DG GROW). Unit C2 - Resource Efficiency and Raw Materials, 14 November, Brussels. 2018.

${ }^{43} \mathrm{HAO}, \mathrm{H}$. , et al., Material flow analysis of lithium in China. Resources Policy, 51, 100-106. 2017.

${ }^{44}$ HAWKINS, T.R., et al., Comparative environmental life cycle assessment of conventional and electric vehicles. Journal of Industrial Ecology, 17, 53-64. 2013.

${ }^{45}$ HELBIG, C., et al., Supply risks associated with lithium-ion batteries. Journal of Cleaner Production, 172, 274-286. 2017.

${ }^{46}$ I.E.A., Market Report Series: Renewables 2017. J. Qual. Participation, 104, 20142. doi:10.1073?pnas.0603395103. 2017.

${ }^{47}$ I.E.A., Energy Technology Perspectives. International Energy Agency. 2017.

${ }^{48}$ I.E.A., Global EV Outlook 2017 - Two million and counting. International Energy Agency. 2017.

${ }^{49}$ JASKULA, B., Lithium. In: Mineral Commodity Summaries. United States Geological Survey. 2016.

50 JASKULA, B., Minerals Yearbook: Lithium. United States Geological Survey. 2018.

${ }^{51}$ JASKULA, B., Lithium. Mineral Commodity Summaries. United States Geological Survey. 2019.

${ }^{52}$ KAVANAGH, L., et al., Global lithium sources - industrial use and future in the electric vehicle industry: a review. Resources, 7(3):57. 2018.

${ }^{53}$ KESLER, S.E., et al., Global lithium resources: relative importance of pegmatite, brine and other deposits. Ore Geology Reviews, 48, 55-69. 2012.

${ }^{54}$ KIM, H.C., et al., Cradle-to-gate emissions from a commercial electric vehicle Li-ion battery: a comparative analysis. Environmental Science and Technology, 50, 7715-7722. 2016.

${ }^{55}$ KLEIJN, R., et al., Metal requirements of low-carbon power generation. Energy, 36, 5640-5648. 2011.

${ }^{56} \mathrm{KÜHN}, \mathrm{A} . \&$ GLÖSER, S., The influence of potential raw material shortages on the market penetration of alternative drives. 15th WCTR, Jully 11-15, Rio de Janeiro, Brazil. 2013.

${ }^{57}$ KUSHNIR, D. \& SANDÉN, B.A., The time dimension and lithium resource constraints for electric vehicles. Resources Policy, 37, 93-103. 2012.

${ }^{58}$ LAMP, P., Requirements for batteries used in electric mobility applications. In: Korthauer, R. (Ed.), Lithium-ion Batteries: Basics and Applications. Springer, pp. 371-291. 2018.

${ }^{59}$ LEADBETTER, J. \& SWAN, L.G., Selection of battery technology to support grid-integrated renewable electricity. Journal of Power Sources, 216, 376-386. 2012.

${ }^{60}$ LEBEDEVA, et al., Lithium ion battery value chain and related opportunities for Europe. Publications Office of the European Union. 2017

${ }^{61}$ LEAL GOMES, C., Estudo estrutural e paragenético de um sistema pegmatoide granítico - o campo aplito-pegmatítico de Arga Minho, Portugal. Tese de Doutoramento, Universidade do Minho, 695 pp. 1994.

${ }^{62}$ LEAL GOMES, C., Análise paragenética das transições de estado e paroxismos evolutivos observados em sistemas pegmatíticos diversificados - Uso de indicadores estruturais, mineralógicos e geoquímicos expressos na Cintura pegmatítica Centro-Ibérica. VII Congresso Nacional de Geologia (J. Mirao \& A. Balbino, eds.), Estremoz, pp. 1169-1175. 2006. ${ }^{63}$ LEAL GOMES, C. \& DIAS, P., Subsídios para uma sistemática dos jazigos minerais e minérios de lítio de Portugal. Boletim de Minas 52 - Edição Especial - Lítio - 2017-2018, 7-47. 2018.

${ }^{64}$ LIMA, A., Estrutura, mineralogia e génese dos filões aplitopegmatiticos com espodumena da região Barroso-Alvão. 
Tese de Doutoramento, Universidade do Porto, 270 pp. 2000.

${ }^{65}$ LIMA, A., et al., As fontes de lítio em Portugal. Revista Portugal Mineral. Edição Especial Indústria Extractiva, 3, 6063. 2011.

${ }^{66}$ LIMA, A.M.C., et al., A ocorrência de petalite como fase litinífera dominante em vários filões do campo aplito-pegmatítico do Barroso-Alvão. Ciências da Terra, Lisboa, pp. F52-F55. 2003.

${ }^{67}$ MARTIN, G., et al., Lithium market research - global supply, future demand and price development. Energy Storage Materials, 6, 171-179. 2017.

${ }^{68}$ MARTINS, L. \& MATEUS, A., Acesso ao território e recursos minerais estratégicos: o lítio como caso de estudo. Boletim de Minas 52, Edição Especial - Lítio - 2017-2018, 113-124. 2018.

${ }^{69}$ MARTINS, T., Multidisciplinary study of pegmatites and associated Li and Sn-Nb-Ta mineralization from the Barroso-Alvão region. Tese de Doutoramento, Universidade do Porto, 196 pp. 2009.

70 MARTINS, T. \& LIMA, A., Pegmatites from Barroso-Alvão, Northern Portugal: anatomy, mineralogy and mineral geochemistry. Cadernos Lab. Xeolóxico de Laxe, 36, 181-208. 2011.

${ }^{71}$ MARTINS, T., et al., Geochemical fractionation of Nb-Ta oxides in Li-bearing pegmatites from the Barroso-Alvão pegmatite field, Northern Portugal. The Canadian Mineralogist, 49, 777-791. 2011.

${ }^{72}$ MATEUS, A. \& MARTINS, L., Challenges and opportunities for a successful mining industry in the future. Boletín geológico y Minero, 130(1):99-121. 2019.

${ }^{73}$ MATEUS, A. \& MARTINS, L., Dez razões para apoiar e incentivar a indústria mineira: globalmente, na UE e em Portugal. Geonovas, 32:(2), 11-40. 2019.

${ }^{74}$ MATHIEUX, F., et al., Critical raw materials and circular economy: background report. JCR Sicence-For-Policy Report. EUR 28832 EN. Publications Office of the European Union, Luxembourg. 2017.

${ }^{75}$ MENAKER, G.I., Theoretical trace-element distributions for igneous rocks. International Geology Review 23, 96-104. 1978.

${ }^{76}$ MESHRAM, P., et al., Perspective of availability and sustainable recycling prospects of metals in rechargeable batteries - a resource overview. Resources Policy, 60, 9-22. 2019.

77 MOHR, S.H., et al., Lithium resources and production: critical assessment and global projections. Minerals, 2 (1):65-84. 2012.

${ }^{78}$ MONGE, M. \& GIL-ALANA, L.A., Automobile components: Lithium and cobalt. Evidence of persistence. Energy, 169, 489-495. 2019.

${ }^{79}$ MOSS, et al., The potential risks from metals bottlenecks to the deployment of strategic energy technologies. Energy Policy, 55, 556-564. 2013.

${ }^{80} \mathrm{NAN}, \mathrm{J}$, et al., Recovery of metal values from a mixture of spent lithium-ion batteries and nickel-metal hybrid batteries. Hydrometallurgy, 84, 75-80. 2006.

${ }^{81}$ NEIVA, A.M.R., et al., Geochemistry of granitic aplite-pegmatite sills and their minerals from Argozelo da Serra (Gouveia, Central Portugal). European. Journal of Mineralogy, 20, 465-485. 2008.

${ }^{82}$ NEIVA, A.M.R. \& RAMOS, J.M.F., Geochemistry of granitic aplite-pegmatite sills and petrogenetic links with granites, Guarda-Belmonte area, central Portugal. European. Journal of Mineralogy, 22, 837-855. 2010.

${ }^{83} \mathrm{NIE}, \mathrm{H}$., et al., $\mathrm{LiCoO}$ recycling from spent batteries and regeneration with solid state synthesis. Green Chemistry 17 , 1276-1280. 2015

${ }^{84}$ NORONHA, F. \& LIMA, A., Da génese à aplicação tecnológica dos aplito-pegmatitos litiníferos da região do Barroso-Alvão e de Almendra. VII Congresso Nacional de Geologia (J. Mirao \& A. Balbino, eds.), Estremoz, pp. 1183-1188. 2006. ${ }^{85}$ OBER, J.A., Lithium. U.S. Geological Survey Minerals Yearbook. 2006.

${ }^{86}$ OLIVEIRA, D.P.S., et al., Lítio em Portugal: enquadramento, geologia e mineralogia. Boletim de Minas 52. Edição Especial - Lítio - 2017-2018, 75-93. 2018

${ }^{87}$ OLIVEIRA, L., et al., Key issues of lithium-ion batteries - from resource depletion to environmental performance indicators. Journal of Cleaner Production, 108, 354-362. 2015.

${ }^{88}$ OLIVETTI, E.A., et al., Lithium-ion battery supply chain considerations: analysis of potential bottlenecks in critical metals. Joule, 1(2):229-243. 2017.

${ }^{89}$ ONAT, N.C., et al., Systems thinking for life cycle sustainability assessment: a review of recent developments, applications, and future perspectives. Sustainability, 9, 706-719. 2017.

${ }^{90}$ ONAT, N.C., et al., Conventional, hybrid, plug-in hybrid or electric vehicles? State-based comparative carbon and energy footprint analysis in the United States. Applied Energy, 150, 36-49. 2015.

${ }^{91}$ ONAT, N.C., et al., Uncertainty-embedded dynamic life cycle sustainability assessment framework: na ex-ante perspective on the impacts of alternative vehicle options. Energy, 112, 715-728. 2016.

${ }^{92}$ ONAT, N.C., et al., Well-to-wheel water footprints to conventional versus lectric vehicles in the United States: a state-based comparative analysis. Journal of Cleaner Production, 204, 788-802. 2018.

${ }^{93}$ PELED, E., et al., Parameter analysis for a practical lithium - and sodium - air electric vehicle battery. Journal of Power Sources, 196, 6835-6840. 2011.

${ }^{94}$ PETERS, J.F., et al., The environmental impact of lithium batteries and the role of key parameters - a review. Renewable and Sustainable Energy Reviews, 67, 491-506. 2017.

${ }^{95}$ PETERS, J.F. \& WEIL, M., A critical assessment of the resource depletion potential of current and future lithium-ion batteries. Resources, 5, 46. 2016.

${ }^{96}$ PETERS, J.F. \& WEIL, M., Providing a common base for life-cycle assessments of Li-ion batteries. Journal of Cleaner Production, 171, 704-713. 2018.

${ }^{97}$ PETERSON, S.B., et al., Lithium-ion battery cell degradation resulting from realistic vehicle and vehicle-to-grid utilization. Journal of Power Resources, 195, 2385-2392. 2010.

${ }^{98}$ POLLET, B., et al., Current status of hybrid, battery and fuel cell electric vehicles: from electrochemistry to market 
prospects. Electrochimica Acta, 84, 235-249. 2012.

${ }^{99}$ PRIOR, T., et al., Sustainable governance of scarce metals: the case of lithium. Science for the Total Environment 461-462, 785-791. 2013.

${ }^{100}$ RAMOS, J.M.F., Mineralizações de Metais Raros de Seixo Amarelo - Gonçalo (Guarda) - Contribuição para o seu conhecimento. Tese de Doutoramento em Geologia, Universidade de Lisboa. 1998.

${ }^{101}$ RAMOS, J.M.F., Mineralizações de Metais Raros de Seixo Amarelo - Gonçalo (Breve Nota). Estudos, Notas e Trabalhos do Instituto Geológico e Mineiro, 42, 67-160. 2000.

${ }^{102}$ RAMOS, J.M.F., et al., Mineralizações de metais raros de Seixo Amarelo - Gonçalo (Breve Nota Introdutória), 31 (2): 101-115. 1994

${ }^{103}$ RAMOS, J.M.F., et al., Evolução geoquímica de pegmatitos LCT da região centro de Portugal no sentido do enriquecimento em lepidolite. VII Congresso Nacional de Geologia (J. Mirao \& A. Balbino, eds.), Estremoz, pp.1193-1198. 2006.

${ }^{104}$ RICHA, K., et al., A future perspective on lithium-ion battery waste flows from electric vehicles. Resources, Conservation and Recycling, 83, 63-76. 2014

${ }^{105}$ RODA-ROBLES, E., et al., Petrogenetic relationships between Variscan granitoids and Li- $(P-P)$-rich aplite-pegmatites in the Central Iberian Zone: geological and geochemical constraints and implications for other regions from the European Variscides. Ore Geology Reviews, 95, 408-430. 2018.

${ }^{106}$ ROSKILL, The economics of lithium. 16th ed. 2018.

${ }_{107}$ RYDH, C.J. \& SVÄRD, B., Impact on global metal flows arising from the use of portable rechargeable batteries. The Science of the Total Environment, 302, 167-184. 2003.

${ }^{108}$ SCHMIDT, O., et al., The future cost of electrical energy storage based on experience rates. Nature Energy, 2, 1-8. 2017.

${ }^{109}$ SCHMIDT, O., et al., Additional emissions and cost from storing electricity in stationary battery systems. Environmental Science \& Technology, 53, 3379-3390. 2019.

${ }^{110} \mathrm{SCHMUCH}, \mathrm{R}$., et al., Performance and cost of materials for lithium-based rechargeable automotive batteries. Nature Energy, 3, 267-268. 2018.

${ }^{111}$ SCHNEIDER, R.P., et al., Preliminary feasibility study for the Kings Valley lithium project. NI 43-101 Technical Report (wWw.Sedar.com). 2012.

112 SCROSATI, B. \& GARCHE, J., Lithium batteries: status, prospects and future. Journal of Power Resources, 195, 2419-2430. 2010.

${ }^{113}$ SCROSATI, B., et al., Lithium-ion batteries. A look into the future. Energy \& Environmental Science, 4(9):3287. 2011.

${ }^{114}$ SEN, B., et al., Material footprint of electric vehicles: a multiregional life cycle assessment. Journal of Cleaner Production, 209, 1033-1043. 2019.

${ }^{115}$ SIMON, B., et al., Potential metal requirements of active materials in lithium-ion battery cells of electric vehicles and its impact on reserves: focus on Europe. Resources, Conservation and Recycling, 104, 300-310. 2015.

${ }^{116}$ Snyder, K., et al., Hybrid vehicle battery technology - the transition from NiMH to Li-ion. SAE Technical Paper, 200901-1385. 2009.

117 SONG, J., et al., Material flow analysis on critical raw materials of Lithium-ion batteries in China. Journal of Cleaner Production, 215, 570-581. 2019.

${ }^{118}$ SOUSA, A.B., et al., Obtenção de concentrados de lítio a partir de diferentes minérios portugueses. Boletim de Minas ,52 - Edição Especial - Lítio - 2017-2018, 95-111. 2018.

${ }^{119}$ STANLEY, C.J., et al., Jadarite, LiNaSiB307(OH), a new mineral species from de Jadar basin, Serbia. European Journal of Mineralogy, 19, 575-580. 2007.

${ }^{120}$ SULLIVAN, J.L. \& GAINES, L., Status life cycle inventories for batteries. Energy Conversion and Management, 58 , 134-148. 2012.

${ }^{121}$ SUN, X., et al., Tracing global lithium flow: a trade-linked material flow analysis. Resources, Conservation and Recycling, 124, 50-61. 2017.

${ }^{122}$ SVERDRUP, H.E., Modelling global extraction, supply, price and depletion of the extractable geological resources with the LITHIUM model. Resources, Conservation and Recycling, 114, 112-129. 2016.

${ }^{123}$ SWAIN, B., Recovery and recycling of lithium: a review. Separation and Purification Technology, 172, 388-403. 2017.

124 TERLOUW, T., et al., Towards the determination of metal criticality in home-based battery systems using a life cycle assessment approach. Journal of Cleaner Production, 221, 667-677. 2019.

125 THE BOSTON CONSULTING GROUP, Batteries for electric cars: challenges, opportunities, and the outlook for 2050. 2010.

${ }^{126}$ U.N.F.C.C.C., Paris Declaration on electro-mobility and climate change \& call to action 2015. 2015.

${ }^{127}$ VAN MIERLO, J., et al., Which energy source for road transport in the future? A comparison of battery, hybrid and fuel cell vehicles. Energy Conversion and Management, 47, 2748-2760. 2006.

${ }^{128}$ VIEIRA, R.C. \& LIMA, A.M.C., Relação geoquímica entre os aplito-pegmatitos da região de Almendra-Souto e os granitos envolventes (NE Portugal). Actas VIII Congresso Geoquímica dos Países de Língua Portuguesa, vol. I, pp. 189-193. 2005.

${ }^{129}$ VIKSTRÖM, H., et al., Lithium availability and future production outlooks. Applied Energy, 110, 252-266. 2013.

${ }^{130}$ WANG, C., et al., Carbon footprint analysis of lithium ion secondary battery industry: two case studies from China. Journal of Cleaner Production, 163, 241-251. 2017.

${ }^{131}$ WEIMER, L., et al., Design of a systematic value chain for lithium-ion batteries from the raw material perspective. Resources Policy, 64, 101473. 2019.

${ }_{132}$ WILBURN, D.R., Material use in the United States - selected studies for cadmium, cobalt, and nickel in rechargeable batteries. Scientific Investigations Report, 2008-5141, USGS. 2009.

${ }^{133} \mathrm{XU}$, J., et al., A review of processes and technologies for the recycling of lithium-ion secondary batteries. Journal of 
Power Sources, 177, 512-527. 2008.

${ }^{134}$ YAKSIC, A.Y. \& TILTON, J.E., Using the cumulative availability curve to assess the threat of mineral depletion: the case of lithium. Resources Policy, 34, 185-194. 2009.

${ }^{135}$ ZACKRISSON, M., et al., Life cycle assessment of lithium-ion batteries for plug-in hybrid electric vehicles - critical issues. Journal of Cleaner Production, 18, 1519-1529. 2010.

${ }^{136}$ ZHANG, C., et al., Charging optimization in lithium-ion batteries based on temperature rise and charge time. Applied Energy, 197, 569-577. 2017.

${ }^{137}$ ZHANG, J., et al., Efficient and economical recovery of lithium, cobalt, nickel, manganese from cathode scrap of spent lithium-ion batteries. Journal of Cleaner Production, 204, 437-446. 2018.

${ }_{138}$ ZUBI, G., et al., The lithium-ion battery: state of the art and future perspectives. Renewable and Sustainable Energy Reviews, 89, 292-308. 2018. 